DANMARKS GEOLOGISKE UNDERSøGELSE

III. RAEKKE. NR. 34

GEOLOGICAL SURVEY OF DENMARK. III. SERIES. NO. 34

\title{
Saltefterforskningen i Danmark
}

Af

Hilmar $\varnothing$ dum

I Kommission hos

C. A. REITZELS FORLAG (JøRGEN SANDAL)

KØBENHAVN 1960 
DANMARKS GEOLOGISKE UNDERSØGELSE

III. RÆKKE. NR. 34

Geological Survey of Denmark. III. Series. No. 34

\section{Saltefterforskningen \\ i Danmark}

Af

H I L MAR ØDU M

I kommission hos

C. A. REITZELS FORLAG (JØRGEN SANDAL)

KøBENHAVN 1960 


\section{INDHOLD}

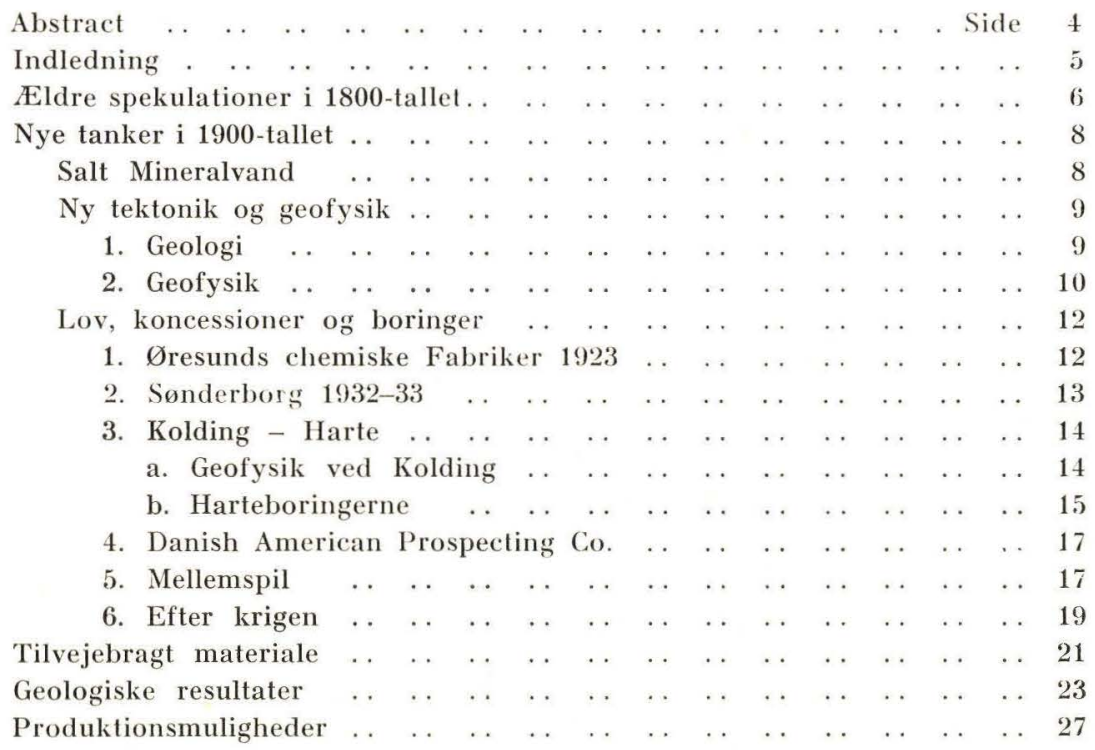

$\begin{array}{llllllllllllllllll}\text { Litteratur } & \ldots & \ldots & \ldots & \ldots & \ldots & \ldots & \ldots & \ldots & \ldots & \ldots & \ldots & \ldots & \ldots & \ldots & \ldots & 32\end{array}$

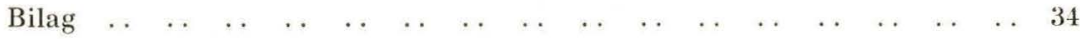




\section{ABS TRACT}

Denmark is heavily covered by Pleistocene Glacial drift deposits resting on Tertiary and Upper Cretaceous formations. The geology of the pre-Cretaceous was unknown until recently.

Shortly after 1920 a number of water borings encountered salt ground water in various parts of the country and several occurences of salt ground water ascending to the surface were simultaneously located by floristical investigations. A survey of the geology of the salt groundwater was subsequently carried out and it was concluded, that part of the salt groundwater might possibly be due to ascending brines from salt deposits in the deep subsurface, and Permian salt formations were suggested.

A mining law was issued in 1932 and exploration work was shortly afterwards started by the Danish American Prospecting Co. Operations were carried on until 1959 when the concession was abandoned.

The extensive exploration work threw light on the formations and structure of the deeper subsurface of Denmark. The most significant results are the following.

An Archaean to Older Paleozoic High divides Denmark in two sedimentary sub-basins which contain relatively deeply lying Permian salt formations superposed by Triassic and Jurassic sequences. A salt dome province is found in Northern Jutland.

Permian and Jurassic formations are partly absent on the Paleozoic High. The basin south of the High constitutes the northernmost part of the North German Sedimentary Basin. 


\section{NDLEDNING}

Indenfor Danmarks geologi kan man vist uden overdrivelse sige, at de væsentligste nye perspektiver i de senere år har ligget i udforskningen af undergrunden, - nærmere betegnet den prækretaciske undergrund. For at formulere det ganske enkelt kunne man gå 20-30 år tilbage og spørge: »Hvad er der under skrivekridtet?

De nye perspektiver er allerede delvis belyst af Albert Gregersen, Th. Sorgenfrei, Aksel Nørvang o.fl. a., og flere forskningsresultater kan ventes.

Det nye kendskab til undergrundens geologi vil ikke alene kaste lys over videnskabelige problemer, - det vil, efter alt at dømme, også få betydelig $\varnothing$ konomisk interesse $\mathrm{i}$ form af salt- og eventuelt kaliproduktion. - Der kan derfor være nogen rimelighed i at give en kort redegørelse for visse træk i efterforskningens historie, en redeg $\varnothing$ relse, der i sin tid påbegyndtes på opfordring af Ministeriet for offentlige arbejder. Selv om det ofte er vanskeligt at skelne mellem rent videnskabelig forskning og praktisk efterforskning, har jeg $s \phi g t$ at begrænse mig til de arbejder, der har haft den sidste tendens. 


\section{ÆLDRE SPEKULATIONER I 1800-TALLET}

Behovet for salt er så elementært et menneskeligt behov, at alle folkeslag til alle tider har haft opmærksomheden rettet mod at få det dækket.

Bor man ved havet, er havet selv naturligvis leverand $\emptyset \mathbf{r}$ af salt, - det er kun et spфrgsmål om inddampning. At inddampning af havvand har været praktiseret til alle tider kan næppe betvivles, selv om egentlige beviser er sjældne (13).

Bor man fjernere fra havet, er saltholdige kilder altid genstand for opmærksomhed, - også i tilfælde, hvor saltholdigheden er ringere end havets. Af historisk kendte fors $\emptyset \mathrm{g}$ på at indvinde salt ad denne vej kan erindres om enkedronning Dorotheas saltværk ved Kolding 1570 (7).

Den geologiske diskussion om saltkilder i Danmark indledes (ud fra mere moderne tankegang) af Forсннаммев 1822 (8). Under omtalen af det interglaciale portlandialer i Vendsyssel (hvis alder FoncHHAMMER på dette tidspunkt fejlbedømte, idet han anså det for at være ældre end kridtet) bemærker han, at »der fremkomme Saltkilder af det, saasom Kilden ved Ørvad, den saakaldte salte Søe ved Hammelmosegaard, i Vildmosen og paa flere andre Steder«, og han sammenligner disse kilder med Saltkilderne i Holsten og Hannover.

BREDSDORFF (4) har studeret de samme forhold i $1823 \mathrm{og}$ skriver med en helt moderne tankegang derom: »Saltkilden ved Ørvad vælder som bekjendt ud af Blaaleer. Den giver overmaade lidet Vand, og dette er af temmelig ringe Styrke. - - Jeg kan ikke troe, at det vilde betale sig at gjøre Anlæg til Saltkogerie paa dette Sted - -. Jeg fik paa denne Rejse ikke Lejlighed til at besøge Lessøe; men den Saltkilde, som der findes, er, efter hvad nogle Borgere i Sæbye sagde mig, af meget større Betydenhed. - - En Vanskelighed gjør det vist nok, at man paa Less $\varnothing \mathrm{e}$ mangler Brændmateriale - -«, og Bredsdorff diskuterer indgående mulighederne for at anvende træ, stenkul fra England, mart $\varnothing$ rv fra Skagen eller t $\varnothing \mathbf{r v}$ fra Jerup Mose, også under hensyn til priserne. Som man ser: ganske de samme problemer, som man må slås med i vore dage. 
I 1826 (5) omtaler BrEdSDORFF atter »Blaaleret« og dets saltkilder og gør sig - i modsætning til Fовсннаммев - til talsmand for, at det må henføres »til de yngste Dannelser«.

Heri får Bredsdorff medhold af C. Pingel, der i det hele taget er meget kritisk indstillet overfor saltprojekterne (28). Om »Salts $\varnothing$ en« ved Hammelmose Mфlle skriver han, at »dens Lødighed er så ringe, at den, selv naar den er stærkest, ikke naaer Vesterhavets Saltholdighed. Derfor hændte det ogsaa, at Saltsøen ikke engang under den sidste $\mathrm{Krig}^{\star}$ ), da Saltmangelen i hine Egne var saa trykkende, lod sig afbenytte med Fordeel. Selv de nærmest Omboende foretrak Anvendelsen af Havvand $\left.--^{\star \star}\right)$. Lige saa uvigtige i salinistisk Henseende synes de $\varnothing$ vrige Saltkilder, som paa flere Steder i Vendsyssel vælde frem af Blaaleret, at være. Under Krigen foranledigede de en Unders $\varnothing$ gelse, hvis Resultater næppe have været tilfredsstillende - - «.

Bjergdirekt $\varnothing \mathrm{r}$ P. Steenstrup (33) slutter sig til Forchhammer's opfattelse af de forskellige lags alder, ligesom han sammenstiller de nordjyske saltkilder med saltkilderne i de holstenske »Fløtsbjerge Han opfordrer til n $\varnothing$ jere unders $\varnothing$ gelser og dybe boringer for at eftersøge »de mægtige lag af de uvurdeerligste Rigdomme af Steenkul og Steensalt«, der må findes i Danmarks undergrund.

Diskussionen går videre, stadig baseret på den formodning, at de omhandlede lerlag er ældre end kridtet. I 1835 (9) er ForchнаммеR dog nået frem til, at blåleret i Vendsyssel hører til »Rullestensformationen«, men alligevel sammenstiller han Vendsyssels Saltkilder med Segeberg og Lüneburg (1. c. pag. 111).

Endelig kommer Forсннаммев 1856 (10) til det resultat, at vandet fra Saltkilderne er, hvad vi nu ville kalde salt residualvand, - omend det er med et suk, han opgiver sin gamle opfattelse!

Hermed endte diskussionen indtil videre.

*) NB: Napoleonskrigen!

**) Her haves altså dokumentation for, at inddampning af havvand praktiseredes. 


\section{NYE TANKER I 1900 -TALLET}

\section{Salt mineralvand}

Saltspekulationerne i begyndelsen af 1800-tallet tog deres udgangspunkt i vendsysselske Saltkilder. I årene efter 1920 begyndte diskussionen påny, men nu baseret på iagttagelser på øerne.

Knud Hee Andersen og Hilmar Ødum publicerede i 1923 en afhandling om en forekomst af saltplanter i en mose N. f. Næstved, fjernt fra havet (2), og Saltplanternes optræden sattes i umiddelbar forbindelse med tilstedeværelsen af saltholdigt grundvand i dræn og boringer. Floraen omfattede 13 halofile arter. Vand fra et dræn indeholdt $4890 \mathrm{mg} / 1 \mathrm{klorid}$, svarende til 0,80\% NaCl. Vand fra en $12 \mathrm{~m}$ dyb boring, stående i kalk, viste $6250 \mathrm{mg} / \mathrm{l}$ klorid, svarende til 1,03\% NaCl.

Efter diskussion af mulighederne for saltvandets oprindelse konkluderedes: »At saltet kan skyldes tilførsel af vand gennem en spalte i kalken og stamme fra dybere liggende, saltrige lag, er vel muligt, ja end ikke usandsynligt; man kender intet tilfælde af den art her fra landet, men derimod i stor udstrækning fra Nordtyskland «.

En lignende halofil flora var allerede 1912 beskrevet af M. J. Mathiassen fra Maglemose ved Mullerup, og endnu nogle lokaliteter af ganske samme type, både fra Sjælland og Fyn, blev beskrevet 1930 af Svend Andersen (3).

Herved var interessen for det saltholdige grundvand blevet vakt, og spørgsmålet om dette saltvands oprindelse trængte sig på. JoHs. ANDERSEN og ØDUM indsamlede et stort materiale af vandanalyser (fra litteraturen, fra Steins anal.-kem. Laboratorium, flere vandforsyningsingeniører o. a.), og dette materiale blev gjort til genstand for en unders $\emptyset$ gelse, der publiceredes 1930 (1). Med få undtagelser hidrørte hele materialet fra landsdelene $\emptyset$. f. Storebælt.

Unders $\varnothing$ gelsen gav til resultat, at grundvand med abnormt stort saltindhold ${ }^{*}$ ) kunne henføres til tre typer (bortset fra direkte forurening) :

*) Normalt indeholder grundvandet sjældent mere end $100 \mathrm{mg} / 1 \mathrm{CI}$. 
1) infiltrationsvand fra havet,

2) residualvand (stagnerende havvand i marine aflejringer),

3) mineralvand, opløsning fra dybere liggende saltlag.

At infiltrationsvand kan forekomme langs kysterne, er selvklart, og muligheden for, at salt residualvand kan optræde, er vel til stede i nogle tilfælde, men det strækker langt fra til som almindelig forklaring. »Størsteparten af de ф́stdanske saltvandslokaliteter må få deres saltindhold gennem tilførsel af opløsninger fra virkelige stensaltlejer«. - »Vender vi os til spørgsmålet om disse prækretaciske saltlejers alder, da har vi intet andet at holde os til end sammenligningen med de nordtyske områder«. Muligheden for saltf $\varnothing$ rende trias nævnes, »men sandsynligheden herfor er ringe, og alt taler for, at det også i Danmark er den stærkt saltf $\varnothing$ rende Permformation, der forsyner de gennem kridtlagene og de andre mesozoiske lag opstigende kilder «.

Den kemisk-geologiske side af sagen uddybedes yderligere i 1936 af Hilmar $\emptyset_{\text {Dum }}$ og Wr. Christensen (38).

Alene koncentrationen af visse saltvandsforekomster var indlysende:

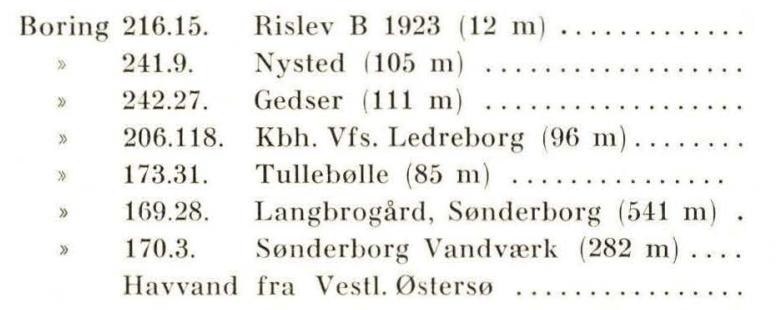

Ny tektonik og geofysik

\section{1) Geologi}

Omtrent samtidig med, at saltvandets optræden skærpede interessen for dets oprindelse, begyndte problemerne med hensyn til undergrundens tektoniske bygning at trænge sig på.

Forestillingerne om jordskorpebevægelser og dertil hørende brud og forkastninger er lige så gamle som geologiske betragtninger overhovedet. Også Forchнамmer(og hans samtidige) regnede med »hævningslinjer af forskelligt forl $\varnothing \mathrm{b}$ i deres tanker om undergrunden. Og i 1899 opsummerer Ussing (34) sine anskuelser i følgende sætninger, der går uændret igen i de senere udgaver af »Danmarks Geologi: »Der er meget, der taler for, at disse Forskydninger eller Spring ikke ere indskrænkede til faa og isolerede Egne, men at de have gjort sig gældende over store Strækninger, hvor de nu skjules ---«. Detail- 
leret kendskab til tektoniske forstyrrelser af vor undergrund havde man dog kun i meget ringe omfang.

I 1918 påviste Victor MADSEN (14), at prækvartæret omkring Mariager Fjord måtte være stærkt forstyrret. I 1925 kom Rosenkrantz til samme resultat med hensyn til kalkundergrunden i Københavns-området (29). Og i 1926 fors $\varnothing$ gte $\emptyset_{\text {Du }}$ (36) at komme forholdene i Jylland nærmere ind på livet: »Det viser sig nu, at visse områder lader sig karakterisere som hævningsfelter, adskilt ved mere eller mindre skarpt markerede sænkningsfelter - - - Som udprægede hævningsfelter må nævnes: Klavsholm-området, Spentrup-området, Nordsalling og Mors, alle omgivne af yngre dannelser, delvis med fremtrædende fald i alle retninger ud fra hævningscentret. Mindre - og i deres bygning mindre kendte - områder er egnen V.f. Lønnerup Fjord, Thyholm, Hjerm, Sevel, Mønsted og Nøvling, samt Skinderup Gårde og Ranum og Vegger (Skrivekridt -) -området. - - Som sænkningsfelter må regnes : Randersdalen, egnen om Hobro, partiet V.f. Vegger III - - o. s. v.«.

Skulle man nå videre, end de rent tilfældige, geologiske observationer tillod, var der kun to veje at gå: omfattende geofysiske undersøgelser og/eller kostbare dybdeboringer. Begge dele lå udenfor, hvad D. G. U. kunne regne med at få bevilling til.

\section{2) Geofysik}

På et internationalt geologm $\varnothing$ de i København 1928 holdt W. WolfF et foredrag, hvori han belyste problemer og opgaver i Danmark, set på baggrund af erfaringer fra Nordtyskland (35). Han gennemgår kendskabet til det saltførende perm i Slesvig og Holsten, »und zwar in solcher Mächtigkeit und Eigenart, dass man auf ein weites unterirdisches Verbreitungsgebiet schliessen muss. Es kann nicht zweifelhaft sein, dass man sie eines Tages im benachbarten dänischen Boden antreffen wird. Auf deutscher Seite reiche Solquellen..... Alle diese Vorkommen stellen uns vor die Aufgabe, den Nordrand der Salzbecken des Zechsteins und die gesamten Verhältnisse noch älterer Salzbildungen aufzuspüren«. Også problemet om olie-forekomster omtales. - Som middel til at gennemf $\phi$ re en sådan udforskning angiver WoLfF først og fremmest de geofysiske metoder, tyngdemålinger og magnetiske målinger, og senere seismik. »Auch in Dänemark wird man zweifellos auf diesem Wege zu genaueren Umrissbildungen der Untergrundsgebirge gelangen .

Et par år tidligere, i 1925, havde $\emptyset_{D U M}$ - i forbindelse med de forannævnte studier over tektonik i Jylland - fors $\emptyset$ gt at bringe magnetiske målinger i anvendelse; det strandede imidlertid på, at Meteorologisk Institut ikke rådede over de nødvendige instrumenter. 
Victor Madsen tøvede ikke med at tage sagen op. Allerede 4/4 1929 ansøger han ministeriet om tilladelse til at begynde magnetisk opmåling; han nævner i sin bredt skrevne ansøgning, at tyngdemålinger og magnetiske målinger er udført af Gradmålingen (Geodetisk Institut) og Meteonologisk Institut, men der foreligger ikke publikationer fra de senere år. MADSEN foreslår nu at begynde arbejdet i Danmark ved samarbejde med »Preussische Geologische Landesanstalt « således, at P. G. L. stiller instrument og personel til rådighed, D. G. U. afholder udgifterne. Undervisningsministeriet godkender planen d. 22/4 1929 med det forbehold, at planen forelægges direktøren for Geodætisk Institut til godkendelse; 11/6 1929 meddeler MADSEN ministeriet, at en sådan godkendelse er opnået. - Denne klausul må formentlig være en lapsus fra Ministeriets side; det danske institut, der måtte være interesseret i magnetisk opmåling, var Meteorologisk Institut. Dettes direktǿr, D. LA Cour, foreslog da også i 1931 et fremtidigt samarbejde med D.G.U., men Victor Madsen svarede bl.a. »at D.G.U. foreløbig betragter de magnetisk målinger som afsluttede for sit vedkommende«.

Den planlagte magnetiske opmåling blev gennemført 1929-30 ved dr. A. Ebert og publiceredes 1932 (6). Af Jylland måltes fra grænsen til en linie Varde-Vejle, og på Fyn V.f. en linie Bogense-OdenseFåborg. Der måltes med Schmidts Lokalvariometer for Vertikalintensitet, med en stationsafstand af $5-1 \mathrm{~km}$ eller stedvis mindre endnu.

Målingerne afslørede tilstedeværelsen af to udpragede »magnetiske maxima ved Vejen og N.f. Harte, der fortolkedes således (15) : » Årsagen til den stærke Intensitet af magnetkraften på disse to ret begrænsede områder må være den, at der i den dybe Undergrund må findes to opragende Bjergmasser, Horste, som vasentlig består af magnetiske, krystallinske stenarter, hørende til grundfjældet. Dr. EвERT og dr. REICH anslår den dybde, hvori grundfjældet findes her, til 1000$1500 \mathrm{~m}$ under overfladen. Vil man gå videre med undersøgelsen af Danmarks undergrund, b $\phi \mathbf{r}$ der f $\phi$ rst og fremmest udf $\phi$ res en dybdeboring på Harte-horsten ned til Grundfjældet, som antagelig ligger mindre dybt på denne horst end på Vejen-horsten. Man vil ved en sådan boring få rede på, om der mellem kridtformationen og grundfjældet findes de geologiske formationer, som kan indeholde petroleum, kalisalte, stenkul og malme«.

Som led i en rent videnskabelig udforskning af vor undergrund, en udforskning, der kunne danne udgangspunkt for senere prospektering, var dette et udmærket program. MADSEN overså blot, at på en højtliggende grundfjældshorst kunne netop de råstofrige formationer, han søgte, være »faldet ud «, ikke være kommet til aflejring. - Det bedste havde været at gennemf $\varnothing$ re en geofysisk opmảling af hele landet, inden man koncentrerede sig om lokale prospekteringsboringer. Det må dog 
straks siges, dels at dette var en opgave, man næppe kunne vente at få midler til, dels at »horstes « og »salthorstes « natur endnu stod noget uafklaret for datidens geologer - og endelig, at udviklingen uventet tog fart efter et andet skema (se s. 15).

For fuldstændigheds skyld skal her kort anføres, at Madsen i 1934 fik opmålt resten af Fyn magnetisk (17) og 1935 Lolland, Falster og Møn (19), og i 1937 Sjælland (22). Disse opmålinger var et interesant led i udforskningen, men fik ikke direkte indflydelse på prospekteringen.

I årene 1930-38 udf $\phi$ rtes i $\varnothing v$ rigt spredte geofysiske unders $\varnothing$ gelser. Foruden de allerede nævnte magnetiske målinger (betalt dels af staten, dels af Laur. Andersens Fond og L. Zeuthens Mindelegat) foretoges magnetiske målinger V.f. Århus (for Århus kommune, 1937); gravimetriske målinger i Nordslesvig - vestl. Fyn (1937, betalt dels af staten, dels af Ravlin, udf. af »Seismos«); gravimetriske, magnetiske og seismiske målinger i dele af Vendsyssel (1937, Ravlin; udf. af A/B »Elektr. Malmletningen«, Stockholm). Ved Kolding udf $\phi$ rtes gravimetriske målinger (Ravlin 1937, »Elektr. Malml.«) og seismiske målinger på initiativ af MADSEN (1933-34; »Piepmeyer u. Co.« og »Seismos«). Hertil kommer yderligere målinger udført af Geodætisk Institut (i særdeleshed de seismiske målinger 1932-33 (26), og tyngdemålinger 1938 (25) og Meteorologisk Institut.

De to sidstnævnte instituters arbejde i disse år var dog $\mathrm{i}$ alt væsentligt led i rent videnskabelige arbejder, uden direkte sigte på prospektering. Nogen koordination med de af Victor Madsen - direkte eller indirekte - inspirerede arbejder fandt ikke sted.

\section{Lov, koncessioner og boringer}

\section{1) Øresunds chemiske Fabriker 1923}

Der var imidlertid andre end videnskaben, der interesserede sig for undergrunden; mulighederne for en praktisk udnyttelse af eventuelle saltforekomster vakte de samme forhåbninger i 1922 som i 1822 .

Ved undersøgelserne ved Rislev kom ØDum og civilingeniør VaLdEMAR OLSEN (dengang ansat ved D. G. U.) i forbindelse med Kryolit-

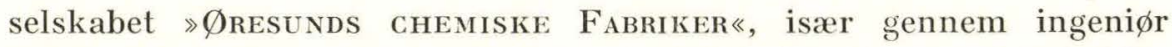
Henry Tuxen. Kryolitselskabet var villig til at sætte en ret betydelig kapital ind på den videre efterforskning i form af en dybdeboring, men man $\emptyset$ nskede givetvis ikke at sætte sådan kapital og efterforskning ind uden en vis beskyttelse i form af en koncession.

Ødum og Olsen søgte 22/1 1923 en sådan koncession, støttet af Victor Madsen (bilag A-B). Koncessionsansøgningen afstedkom ad- 
skillig forvirring i ministerierne, hvor tanken om noget sådant var ny og ukendt, og sagen gik fra det ene ministerium til det andet. At det ikke alene var bristen på lovhjemmel, der spillede ind (et forhold, der vel kunne ændres - og blev ændret 9 år senere), fremgår af et brev fra VALD. OLSEN 30/7 1923: »Der kom brev fra Undervisningsministeriet, at undervisningsminister APPEL $\emptyset$ nskede at tale med en af os angående den projekterede dybdeboring. Jeg gik så derop; men mit indtryk af den høje Excellence bryder jeg mig ikke om at nedskrive, han begyndte: »Nå, så det er Dem, der tror, at man kan forbyde en mand at gøre på sin jord, hvad han vil; « det lød opmuntrende; for $\varnothing$ vrigt ville han mig ikke noget, nærmest blot se, hvordan vi så ud ... Et m $\varnothing$ de hos handelsministeren fik et noget lignende forløb. Og den 11/9 $1923 \mathrm{kom}$ afslaget (bilag C). - Umiddelbart kunne man fristes til at beklage dette udfald, men set i lyset af vor senere viden, var det vist meget godt, at det gik, som det gik. Saltet under Rislev ligger meget dybt; nogen salthorst er der ikke tale om (1 s.94).

\section{2) Sф̆nderborg 1932-33}

Uafhængigt af de videnskabelige undersøgelser - såvidt det kan ses var der imidlertid folk på færde med ønskekvisten! To tyskere støttet af et par danske forretningsmænd - berejste $\emptyset$ stjylland sammen med en tysk фnskekvistmand, og denne »påviste« bl. a., at der ved Langbrogård i Dybbøl Sogn fandtes salt i en dybde af $235 \mathrm{~m}$, og kalisalte ved $280 \mathrm{~m}$, og på dette grundlag udf $\varnothing$ rtes i 1932-33 to boringer til dybder af $481 \mathrm{~m}$ og $541 \mathrm{~m}$ - begge stående i skrivekridt (169.28 a-b). Saltvand optrådte, men fast salt fandtes ikke, og en seismisk undersøgelse, der iværksattes på Victor MADsens initiativ, viste, at fast stensalt ikke fandtes i de angivne dybder. Victor Madsen har udf $\phi r l i g t$ beskrevet det hele mærkværdige foretagende $(16,18)$.

Set fra et forsknings- og efterforskningsmæssigt synspunkt var denne affære så urationel som vel tænkeligt. Alligevel virkede den som en kortslutning i langtidsprogrammet: vi fik en dansk minelov!

Ing. W. MEyer forberedte boringerne ved Langbrogaard i efteråret 1931, og da disse undersøgelser tegnede til at ville blive gennemf $\varnothing \mathbf{r t}$ og da de sigtede direkte på anlægget af et saltværk - henvendte Victor Madsen sig 27/10 1931 til statsministeriet med forslag om, at den savnede bjergværkslovgivning tilvejebragtes (bilag D-E).

Loven udstedtes 19/2 $1932 \mathrm{og}$ indeholdt principielle bestemmelser om statens ejendomsret til råstoffer, der ikke havde været privat$\emptyset$ konomisk udnyttede indtil udstedelsesdagen, regler for udstedelse af efterforsknings- og indvindingskoncessioner m. v. Desuden knæsatte 
loven - og de senere bekendtg $\phi$ relser - principet om statens ubegrænsede ret til kontrol, ikke alene med udvinding men også med efterforskning. Herved blev det muligt for fremtiden at samle alle vigtige oplysninger på D. G. U. - Loven har været underkastet flere ændringer, senest revideret $8 / 51950$, men uden principielle æendringer.

\section{3) Kolding-Harte}

a) Ge of y sik ved Kolding

Loven kom først til anvendelse ved de foran omtalte saltboringer ved Langbrogård. Disse unders $\varnothing$ gelser gav intet resultat, men som et led i de indviklede finansieringsanstrengelser var der 3/10 1932 blevet stiftet et dansk selskab, »Boreaktieselskabet Dybb $\varnothing$ l-S $\varnothing$ nderborg «, og VICToR MADSEN tog initiativet til at lade dette selskab interessere sig for Kolding-egnen. Med tilslutning fra interesserede folk i Kolding skaffedes den n $\varnothing$ dvendige kapital, og seismiske unders $\emptyset$ gelser udf $\varnothing$ rtes på h $\emptyset$ sten 1933 omkring Harte og gav bl.a. visse resultater, der tydedes som bevis for tilstedeværelse af stensalt (»Piepmeyer u. Co.«). - Da pengene var brugt op, skaffede MADSEn en bevilling fra statsministeriet på 24.000 kr., og nye unders $\emptyset$ gelser udf $\phi$ rtes (af »Seismos«, og under medvirkning af professor O. Barsch, Berlin) i 1934. Også disse unders $\emptyset$ gelser kunne måske tyde på tilstedeværelsen af salt (21 s. 231).

Saltet var dog kun »påvist《 indenfor et område af $200 \mathrm{~m}$ udstrækning, og i en dybde af ca. $700 \mathrm{~m}$. - Af de to firmaer synes »Piepmeyer « at være mindst forbeholden, når det (i MaDSENs oversættelse) hedder : » dette profil fandtes mellem seismograferne ${ }^{\star}$ ) et materiale, som i seismogrammerne viste de for salt karakteristiske egenskaber, altså en kort periode med ringe amplitude (salttakker), så vel som en for salt typisk klangfarve af knaldet $-\ll$. »Seismos« er betydeligt forsigtigere: » Det $\mathrm{i}$ en dybde af ca. $700 \mathrm{~m}$ fundne $3900 \mathrm{~m} / \mathrm{s}$ lags geologiske natur må stå hen. Det samme gælder for zonerne med endnu st $\varnothing$ rre hastighed « (bilag F). Prof. Barsch konkluderer i sin sammenfattende bed $\varnothing$ mmelse: $\gg I$ hvert tilfælde er de uregelmæssige og små områder med de store hastigheder af for ringe udstrækning til, at disse hastigheder kan skyldes saltdomer. I hele det unders $\emptyset$ gte område er der ikke fundet noget som helst, som tyder på tilstedeværelsen af saltdomer« (bilag G).

Geofysiske resultater kan kun fortolkes med større eller mindre sikkerhed, hvis man har påtagelige geologiske udgangspunkter i form af forhåndskendskab til egnen eller dybere boringer. De hidtil tilvejebragte resultater omkring Harte ville have været et udmærket grundlag for anbringelsen af en eller flere opklaringsboringer (»stratigrafiske

*) D. v. s. i profil 4a, imellem to seismografer ved Paaby, med en afstand af ca. $190 \mathrm{~m}$ (16 s. 286). 
boringer«), hvorfra man så evt. kunne slutte videre. Dette var, som vi har set foran, også MADSENS oprindelige tanke (s. 11 »Vil man gå videre $-\ll)$.

Det synes imidlertid, som om MADSEN i sin forståelige begejstring gik lidt for hurtigt videre. Vi har set, hvorledes forsigtigheden i udtalelserne stiger fra Piepmeyer gennem Seismos til Barsch; men i sin endelige indberetning til statsministeriet af 17/1 1935 skyder MADsen forsigtigheden til side: »For mig er der ingen tvivl om - - - - at der virkelig findes salt der, hvor der er fundet en hastighed af $5000 \mathrm{~m} / \mathrm{s}$, men desværre er der ingen saltdomer fundet i det unders $\emptyset$ gte område« (bilag $\mathrm{H}$ ).

Det lille ord »desværre« er talende, men man må give Madsen ret $\mathrm{i}$, at der godt kan være stensalt tilstede i en serie, selv om det ikke er $\mathrm{i}$ form af salthorste (saltdomer). At salt $\mathrm{m}$ å $\mathrm{t} \mathrm{e}$ være tilstede, fremgik uomtvisteligt af salt i grundvandet. Men begejstringen - og den opdukkende Mr. Ravlin - forvandlede en evt. opklaringsboring til en af koncessionsløfter tynget prospekteringsboring.

Victor Madsen har skitseret sagens udvikling (21 s. 232), og i enkeltheder kan den f $\varnothing$ lges i ministeriet for offentlige arbejders betænkning, »Saltfundet ved Harte den 13. november 1936 « (12). Her skal kun fastholdes nogle hovedpunkter i udviklingen, idet der erindres om, at hovedinteressen nu forskydes fra salt til olie; prospekteringsformerne (geofysiske og geologiske unders $\emptyset$ gelser) måtte dog indtil videre blive de samme.

\section{b) $\mathrm{H}$ a r teboringerne}

Forbindelsen mellem Victor Madsen og Fred Ravlin var tilvejebragt af ingeniør Karl Østman i løbet af 1933-34, og Ravlins foreløbige ans $\varnothing$ gning om tilladelse til at $\gg$ bore efter olie i Danmark « foreligger $3 / 81934$ (bilag I). I statsministeriets svar af 28/9 1934 er tilladelsen begrænset til egnen »omkring Kolding By«; der gives heri ikke nogen indvindingstilladelse; dette måtte evt. forhandles senere (bilag $\mathbf{J}$ ).

Sagen forhandles videre, og den af $g \phi$ rende efterforskningskoncession udstedes 25/1 1935: »Under forudsætning af . . . . meddeler statsministeriet Dem herved tilladelse til efterforskning af olie, gas, salt og andre råstoffer i Kongerigets Danmarks undergrund ..... Betingelserne i $\S 3$ i Lov om Efterforskning og indvinding af råstoffer i Kongeriget Danmarks undergrund af 19. febr. 1932 .... skal opfyldes efter nærmere anvisning af Danmarks geologiske Undersøgelse ..... For så vidt et af de ommeldte råstoffer findes i Danmark, vil ministeriet . . . . . meddele bevilling til med eneret at efterforske og indvinde olie, gas, salt og andre råstoffer i Kongeriget Danmarks undergrund, Færøerne undtaget, for Dem i et tidsrum af 50 år .... . 
Nu var det fastslået, at fundet af blot et af råstofferne automatisk ville føre til indvindingskoncession for dem alle i hele landet i 50 år!! Og herved kom saltet atter ind i billedet.

Efter »Saltfundet« d. 13/11 1936 kunne Ravlin 17/11 1936 begære en sådan koncession: »Da ingeniør Ravlin har fundet råmaterialet salt - anmoder han nu om at få en skriftlig bekræftelse fra ministeriet om, at han nårsomhelst inden den 15. juli 1938 på begæring kan få meddelt bevilling til med eneret at efterforske og indvinde olie, gas, salt $\mathrm{og}$ andre råstoffer . . . . . i et tidsrum af 50 år «. Den således $\phi$ nskede eneretsbevilling udstedtes - efter forhandlinger - den $7 / 21938$ til »Danish American Prospecting Co., Miami, Florida Ravlin. Og Ravlin kunne i sin tur overdrage aktierne i DAPCo til 》Gulf Refining Company (12 s. 90).

Ravlin udf $\varnothing$ rte to boringer ved Harte, D. G. U. nr. 133.108 a-b. Den første på begyndtes 27/7 1935 og afsluttedes 21/7 1936 på grund af teknisk uheld; den var da nået ned til $791 \mathrm{~m}$, stående i hårdt kridt med flint - utvivlsomt det, der ved de seismiske unders $\varnothing$ gelser havde givet de store hastigheder!

Den anden boring påbegyndtes 2/3 1936, afbrødes 14/11 1936 og fortsattes 16/4 1937-16/8 1937: Den nåede ned til $1096 \mathrm{~m}$. Ved denne boring lykkedes det for første gang i Danmark at gennembore de mægtige kridtaflejringer.

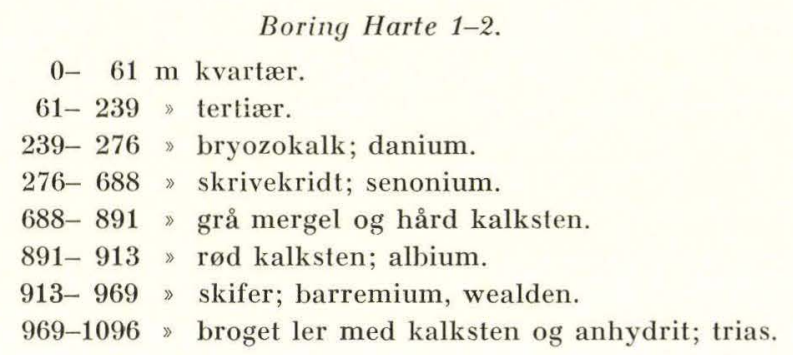

Ved kærnetagning i denne boring fremkom 13/11 1936 et $17 \mathrm{~cm}$ langt stykke stensalt, fra dybden $956-959 \mathrm{~m}$, over- og underlejret i kærnetageren af andre bjergarter.

Forekomsten af dette salt ansås for ægte (21 s. 234), og fundet gav anledning til udstedelsen af den ovenfor omtalte koncession af $17 / 2$ 1938.

Senere har det vist sig, at dette saltstykke må anses for et falsum, anbragt i kærnetageren i den hensigt at opnå den meget omfattende koncession (12). Den utvivlsomme optræden af salt mineralvand ved Harte--Kolding må antages at hidrø̆re fra saltudskillelser i triaslagene. Perm konstateredes ikke ved Harte, og set i lys af senere boringer er 
det ikke usandsynligt, at triaslagene kan hvile direkte på dannelser ældre end perm.

De s. 12 omtalte gravimetriske målinger ved Harte og i Sønderjylland skete i tilslutning til boringen 1937. Salthorste konstateredes ikke med nogen sikkerhed (20 s. 374).

\section{4) Danish American Prospecting Co.}

Tvivlen om Harte-saltets ægthed kom f $\varnothing$ rst frem senere (se 12 s. 10). Efter »fundet《 13/11 1936 borede Ravin videre i 1937 uden at konstatere mere salt. 7/2 1938 fik han udstedt sin indvindingskoncession, stilet til det af ham oprettede »Danish American Prospecting Co.« indregistreret i Danmark 30/11 1937. I april 1938 ansøgte RavLIN om tilladelse til eventuelt at »bortforpagte s sine rettigheder; 20/5 1938 lovede ministeriet velvillig behandling af dette spørgsmål, og 22/8 1938 solgte Ravlin aktierne i DAPCo til Gulf Refining Company. Hermed overtog Gulf eneretten til de kommende års prospekteringer i Danmark, og det egentlige Danish American Prospecting Co. var etableret. - Den 17/2 1940 sluttedes en tillægsoverenskomst mellem statsministeriet og dette nye DAPCo, indeholdende bl. a. regler for samarbejdet mellem DAPCo og de danske videnskabelige instituter, tilsynets rettigheder og pligter, evt. forsyning af hjemmemarkedet under givet behov m. m. (bilag $\mathrm{K}$ ).

På det geofysiske område kom det ikke til noget vidtgående samarbejde mellem DAPCo og instituterne. DAPCo indledte i årene f $\varnothing \mathrm{r}$ krigen sit efterforskningsarbejde med en meget detailleret gravimetrisk opmåling af hele landet, og hertil $\phi$ nskede man at benytte sit eget »Gulf Gravimeter«, bl. a. også fordi måleresultaterne skulle bearbejdes af Gulfs egen geofysiske afdeling i U.S. A.

Ved tilrettelæggelsen af dette arbejde fandt iøvrigt et samarbejde sted mellem DAPCo og D.G. U.; DAPCo besluttede sig til at begynde sin gravimetriske opmåling i det nordlige Jylland, fordi man her kunne st $\varnothing$ tte fortolkningen på det almindelige geologiske materiale, D. G. U. kunne stille til rådighed.

\section{5) Mellemspil}

Den 9. april 1940 standsede DAPCo's arbejde, og de amerikanske medarbejdere forlod landet.

I visse kredse fandtes nogen utilfredshed med, at »Stauning havde solgt undergrunden «, man overså - bortset fra følelsesmæssige motiver - at det på een gang va r i statens interesse at få en grundig efterforskning igang, og samtidig praktisk umuligt at tilvejebringe de 
meget store bel $\varnothing b$, en rationel efterforskning ville kræve; i tiden mellem lovens vedtagelse og RAvLins opdukken - $2 \frac{1}{2}$ år - havde MADSEN forgæves s $\emptyset$ gt at interessere dansk kapital for sagen. At man med rette kunne have $\phi$ nsket et nærmere samarbejde mellem DAPCo og de danske instituter, var en anden sag, men overenskomsten herom af 17/2 1940 var kun nogle uger ældre end 9. april.

Under krigens afspærring forekom flere forsøg på at få koncessionen over på danske hænder (se herom især 12), - de fleste ret naive med hensyn til de formodet n $\varnothing$ dvendige pengemidler. Statsministeriet indtog konsekvent det standpunkt, at en overtagelse eller videref $\phi$ relse af DAPCo's arbejde kun kunne ske ved overenskomst med DAPCo, da koncessionen var amerikansk ejendom. Dette faktum reddede os utvivlsomt fra en tysk-dirigeret olieefterforskning under krigen.

Noget vanskeligere blev situationen, efter at alle undergrundssager 2/12 1942 blev flyttet fra statsministeriet til ministeriet for offentlige arbejder. Trods protest fra DAPCo's herværende repræsentant $\varnothing$ nskede minister Gunnar Larsen og »Teknisk Central« under nævnte ministerium efterforskningsarbejdet videref $\varnothing \mathrm{rt}$, også i form af boringer.

Der nedsattes et »arbejdsudvalg《 under forsæde af dette ministeriums tilsynsf $\varnothing$ rende, professor, rektor Anker Engelund, og med de tre institutchefer (Helge Petersen, N. E. NØrlund, H. Ødum) + direkt $\varnothing$ r Erik Kayser, Tekn. Central, som medlemmer. Arbejdsudvalget udfoldede gennem nogen tid en virksomhed i form af videnskabelige geofysiske opmålinger, boringer på mindre vigtige steder m.m. - alt med det formål at forhale tiden og forhindre iværksættelsen af politisk kompromitterende virksomhed; efter 29. august 1943 gik arbejdet i stå.

En særlig komplikation opstod, da visse rygter om upålideligheden af det tilgrundliggende saltfund ved Harte kom til minister GunNar Larsens kendskab. Ministeren lod iværksætte en undersøgelse, men denne blev afbrudt og f $\varnothing$ rst genoptaget efter krigen ved nedsættelse af »Udvalget af 24/1 1946 til Revision af Undergrundslovene«, der også fik til opgave at undersøge spørgsmålet om ægtheden af saltfundet. Hvad dette spørgsmål angår, sluttede udvalget sit arbejde i juli 1948 med udsendelse af den tidligere nævnte betænkning om »Saltfundet ved Harte« (12). Efter en overordentlig grundig udredning af bele sagen samler udvalget sin opfattelse i en konklusion, hvori fremhæves, at der ikke foreligger tilståelse om bedrageri, men så mange og så vægtige indicier, at udvalget må »hævde som sin opfattelse, at det ved Ravlins boring den næevnte dag fremkomne saltstykke ikke hidrører fra Harte, og at Ravlin har begået et bedrageri overfor den danske stat ved til opnåelse af koncession at påberåbe sig saltstykket som en fra undergrunden ved Harte hidr $\phi$ rende borekærne« (12 s. 69). 
Inden alt dette skete, var koncessionen allerede 1938 gået fra RAvLins hænder over på GuLFs, og der var ikke under sagen fremkommet noget som helst, der kunne indicere de nye koncessionsejeres medskyld eller medviden.

Sammenholdtes dette med statens $\phi$ nske om en videref $\phi$ relse af undersøgelserne på et for staten fordelagtigt grundlag, måtte udvalgets videre arbejde gå ud på at tilvejebringe et sådant grundlag (bilag L) . Undergrundsloven af 1932 var faktisk udløbet 1/7 1940, men på dette tidspunkt var en revision umulig, så loven blev successive forlænget uændret. - Nu udstedtes en revideret lov 8/5 1950, med derpå baseret overenskomst og ny eneretsbevilling til DAPCo, bekendtgjort 8/8 1950 . Uden ændring af tilgrundliggende principper indeholdt disse akter både en række klargøringer og en række fordele for staten.

\section{6) Efter krigen}

Danish American Prospecting Co. havde imidlertid genoptaget sit arbejde efter krigen, og det var fortsat $\mathrm{i}$ intensiveret form uden hensyn til de foran omhandlede begivenheder.

DAPCo havde - som omtalt s. 17 - baseret sit efterforskningsarbejde på et detailleret geofysisk opmålingsarbejde. Hele landet dækkedes af et net af gravimetriske stationer, ialt 18.682, da arbejdet var fuldf $\varnothing$ rt i 1948; stationsafstand gennemsnitlig ca. 1,6 km. De tilvejebragte tyngdekort afslører ved passende reduktion o. a. bearbejdning såvel dybtliggende, regionale strukturer i undergrunden (i analogi med de tidligere omtalte magnetiske kort) som lokale anomalier.

I tilknytning til - og i fortsættelse af - tyngdemålingerne har DAPCo gennem hele sin virksomhedstid i Danmark foretaget seismiske undersøgelser, til nærmere udredning af de oplysninger, gravimetrien giver. Denne metode bekræftede bl. a., at visse strukturer i Jylland måtte være salthorste.

Allerede f $\phi \mathrm{r}$ krigen havde DAPCo som f $\phi$ lge af disse rekognosceringer påbegyndt en boring på »M $\varnothing$ nstedstrukturen « - den blev afbrudt i 1940 uden at være nået gennem kridtet. Nu genoptoges boringerne efter krigen ved Vejrum (N.f. Holstebro), og 3/6 1946 nåede boringen Vejrum 1 fast stensalt i en dybde af $240 \mathrm{~m}$.

Vejrum 1 (64.233).

0 - 24,4 m sand og grus; kvartær

$24,4-27,5$ » tertiært ler

$27,5-80,8 »$ kalk; danium

80,8-173,7 » skrivekridt; senonium

173,7-240,8 » "caprock ": gips, anhydrit, ler, dolomit o. a.

240,8-302,7 » stensalt med lag af anhydrit; perm. 
Fortsatte boringer - delvis til større dybde - fastslog tilstedeværelsen af en regulær salthorst; boringer tæt udenfor horstens rand nåede til $550 \mathrm{~m}$ dybde stående i kridt.

Flere salthorste påvistes ved det fortsatte arbejde (se s. 26-27).

Foruden nogle få boringer f $\varnothing$ r krigen udf $\varnothing$ rte DAPCo i årene 1946-54 under ledelse af Alb. Gregersen, C. W. Flagler, og Aug. Pyre 159 dybere boringer, dels til opklaring af stratigrafi, dels til afgrænsning og nærmere undersøgelse af strukturer, hvor der var håb om at finde salt eller olie. Disse boringer gav naturligvis en enorm fylde af oplysninger, men håbet om at finde olie i udnyttelig form og mængde gik ikke i opfyldelse; kun svage oliespor blev truffet enkelte steder.

DAPCo fik - i overensstemmelse med loven - tilladelse til midlertidigt at lade efterforskningsarbejdet indstille 1/2 1954. Bearbejdelsen af alle de tilvejebragte oplysninger blev dog fortsat, og arbejdet i marken genoptoges atter $1 / 2$ 1956, denne gang med »STandard OiL of NEw JERSEY « som ejere af aktiekapitalen, og 1957-59 udf $\phi$ rtes under ledelse af C. D. Alworth og J. M. Dorreen 11 dybe boringer stadig uden oliefund.

Så indstilledes arbejdet definitivt, og koncessionen opgaves $30 / 6$ 1959. Danish American Prospecting Co. eksisterede ikke mere. 


\section{TILVEJEBRAGT MATERIALE}

Som nævnt s. 14 indeholder loven af $1932 \mathrm{~m}$. v. bestemmelser om, at D. G. U. har ret til at erholde alle oplysninger om udførte boringer, ret til udtagelse af borepr $\phi$ ver og forsteninger m. v. Endvidere indeholder eneretsbevillingerne bestemmelser om samarbejde mellem DAPCo og de videnskabelige instituter, og om samarbejde mellem koncessionshaverne og statens tilsyn.

På basis heraf har der gennem alle årene indtil 1959 fundet et udstrakt samarbejde sted mellem DAPCo og D. G. U.

Ialt har DAPCo til og med 1959 udf $\varnothing \mathrm{rt}$

ialt dybere boringer: 170 stk. ${ }^{*}$ )

heraf: stående i nedre kridt: 40 stk.

stående i salthorste: 33 »

stående i prækretaciske

aflejringer udenfor

salthorste: 31 »

altså ialt 104 »egentlige dybdeboringer «,

ført igennem skrivekridtet.

Det materiale, der er tilgået D. G. U., er imidlertid langt mere omfattende, end loven foreskriver. DAPCo har indtaget det standpunkt, at alt kærnemateriale overlodes D.G.U., så snart selskabet havde afsluttet sin egen bearbejdelse deraf. Og endelig overgaves ved ophøret i 1959 alt DAPCo's materiale til D. G. U.: kærneprøver, skylleprøver fra dybdeboringerne, foraminiferpræparater, seismiske diagrammer, rapporter af enhver art, kortmateriale o. m. a.

Herefter har D.G.U. i DAPCo's samlede efterforskningsperiode modtaget ialt følgende antal prфver fra dybdeboringer:

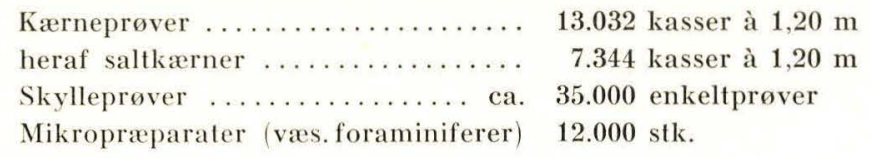

*) Heri medregnet Harteboringen. 
Hertil må føjes, at DAPCo i samme tidsrum har afgivet til D. G. U. profiler - og tildels prøver - fra ca. 12.500 shot-holes. De mange shotholes for sprængningerne til de seismiske undersøgelser når i almindelighed kun dybder af $20-50 \mathrm{~m}$, men de udg $\phi \mathrm{r}$ et særdeles vigtigt supplement til borearkivets almindelige tilgang af vandboringer $\mathrm{m}$. v.

Seismiske diagrammer ........... ca. 28.000

Rapporter hertil .............. ca. 600 


\section{GEOLOGISKE RESULTATER}

Dette enorme materiale for $\varnothing$ ger vort kendskab til Danmarks geologi ganske overordentligt.

Det er indlysende, at det vil kræve lang tid til tilfredsstillende bearbejdelse bortset fra de former for bearbejdelse, der umiddelbart giver svar - positive eller negative - på rene prospekteringsspørgsmål. En forberedende bearbejdelse, der i oversigtsform giver svar på de nærmestliggende geologiske spørgsmål, er i gang, og resultaterne vil snart kunne trykkes.

Visse sider af den helt nye prækretaciske geologi er allerede publiceret (11.24. 2\%.31.32.3\%.39.40), og på grundlag heraf øjner man de store træk af vor undergrunds geologi: den skånske brudzones fortsættelse mod NV. til Frederikshavn-Skagen, og det hævningsområde af grundfjeld og/eller ældre palæozoicum, der strækker sig fra Ringk $\varnothing$ bingegnen mod $\emptyset \mathrm{S} \emptyset$. over Fyn til Lolland (-Falster?); dets begrænsning er dog kun omtrentlig fastslået.

Nordjylland-Sjælland udgør et sænkningsområde med formodentlig 3000-4000-5000 m mægtige sedimenter, omfattende perm-trias-jurakridt; i Nordjylland adskillige salthorste. - Syd for hævningsområdet Ringk $\phi$ bing-Fyn findes et andet sænkningsområde med perm-triaskridt; sedimentmægtigheder mindst $3000 \mathrm{~m}$. - På hævningsområdet savnes jura og perm (i hvert fald af nogen betydning); trias er tilstede, men ved Glamsbjerg f. ex. hviler nedre kridt direkte på arkose og gnejs i $900 \mathrm{~m}$ dybde. - Salthorste er ikke påvist udenfor det nordjyske område, heller ikke geofysisk (32).

De to sænkningsområder repræsenterer to tidvis adskilte sedimentationsområder. I yngre perm, zechstein, har en bugt fra oceanet dækket hver af dem (om der har været forbindelse mellem dem i det SØ. Danmark er uvist). Ved periodevis hel eller delvis afspærring fra havet skabtes forudsætning for stærk inddampning og afsætning af evaporiter: kalksten og dolomit - anhydrit - stensalt - kalisalte, i den nævnte rækkef $\varnothing$ lge. En inddampningscyklus nåede selvf $\varnothing$ lgelig ikke altid til ende; afsætningen af kalisalte finder ikke sted i alle cykler.

På dansk område har Sorgenfrei kunnet konstatere 5 cyklers tilstedeværelse (se s. 25-26). 


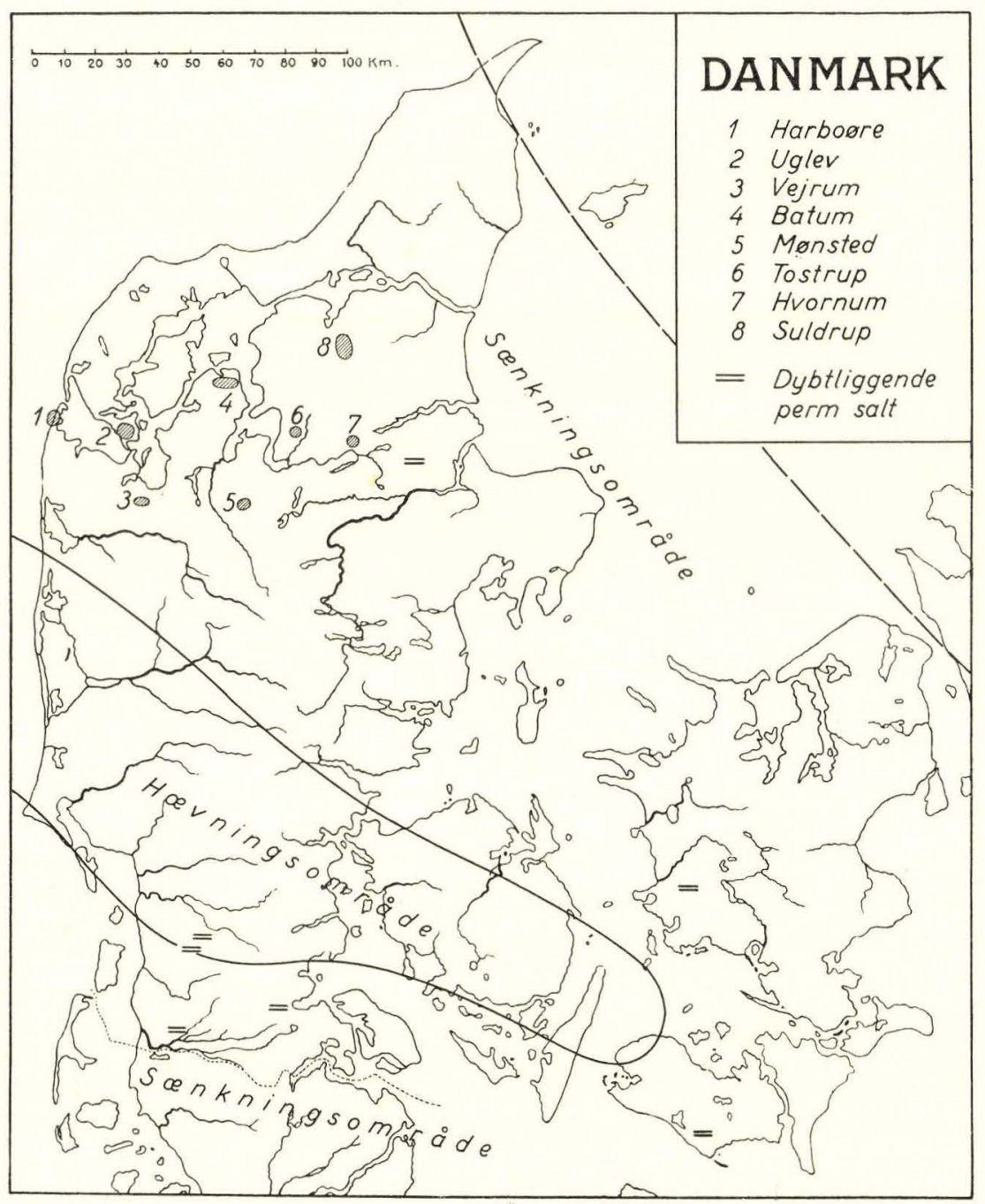

Fig. 1. Forekomst af Perm i boringer i Danmark. 1-8: salthorste i Nordjylland. Med signatur: dybtliggende perm-salt.

Boring Tфnder E nr. 2 ved Abild (166.232) har følgende profil (stærkt forenklet):

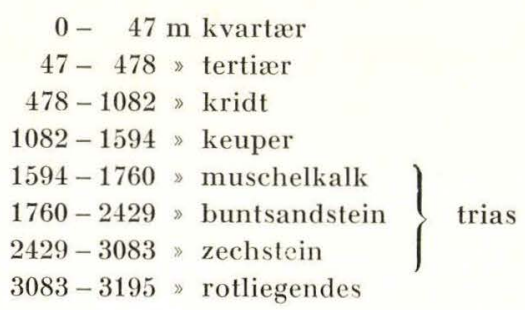




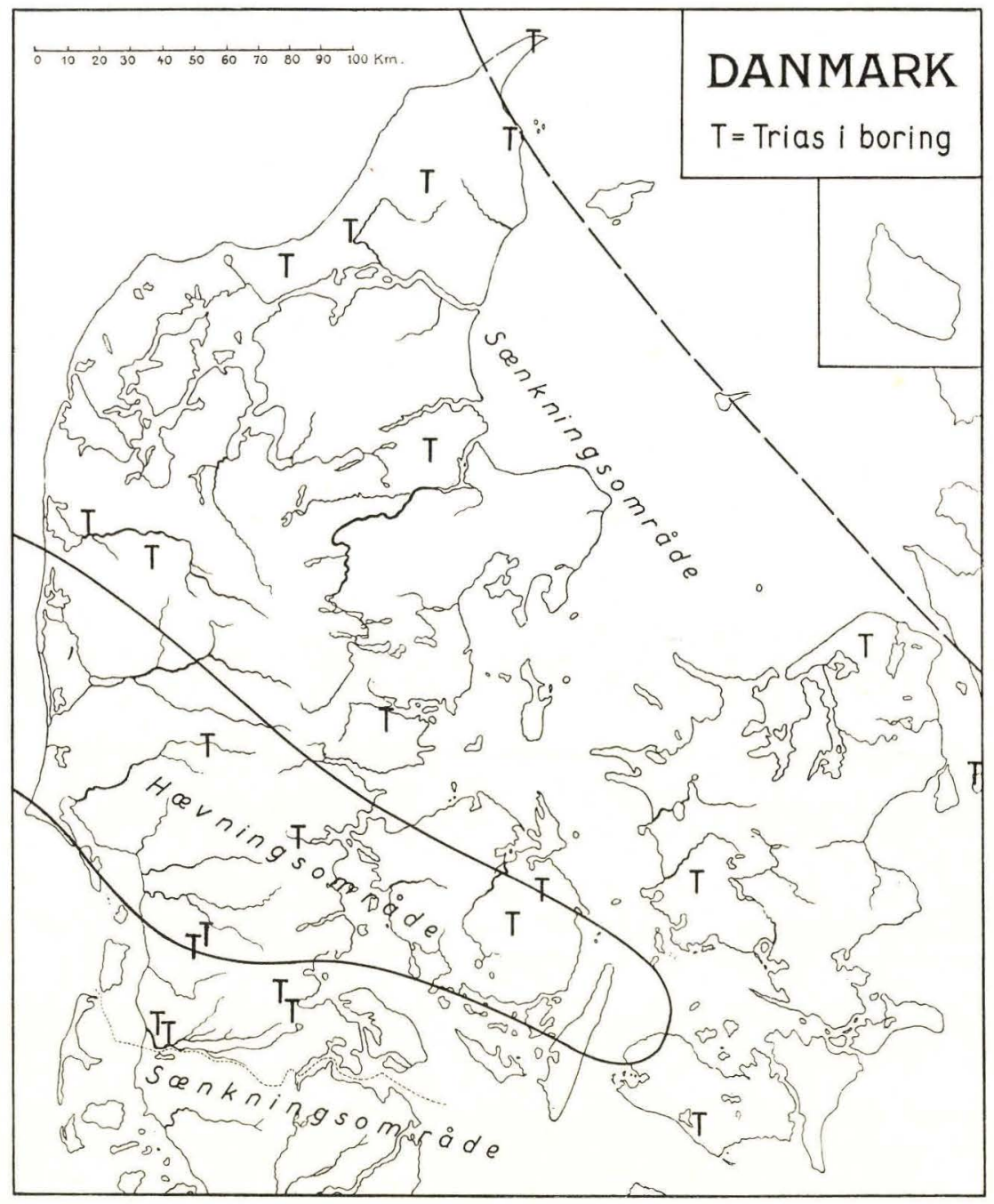

Fig. 2. Forekomst af Trias i boringer i Danmark.

Zechsteinserien $2429-3083(=\div 2416-\div 3071)$ har Sorgenrrei inddelt på følgende måde (31):

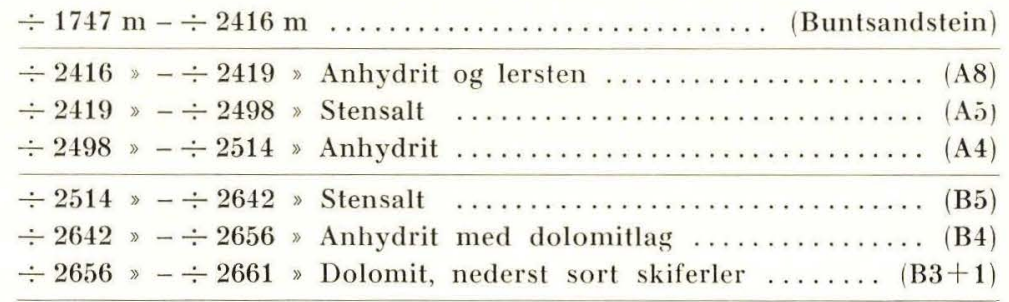




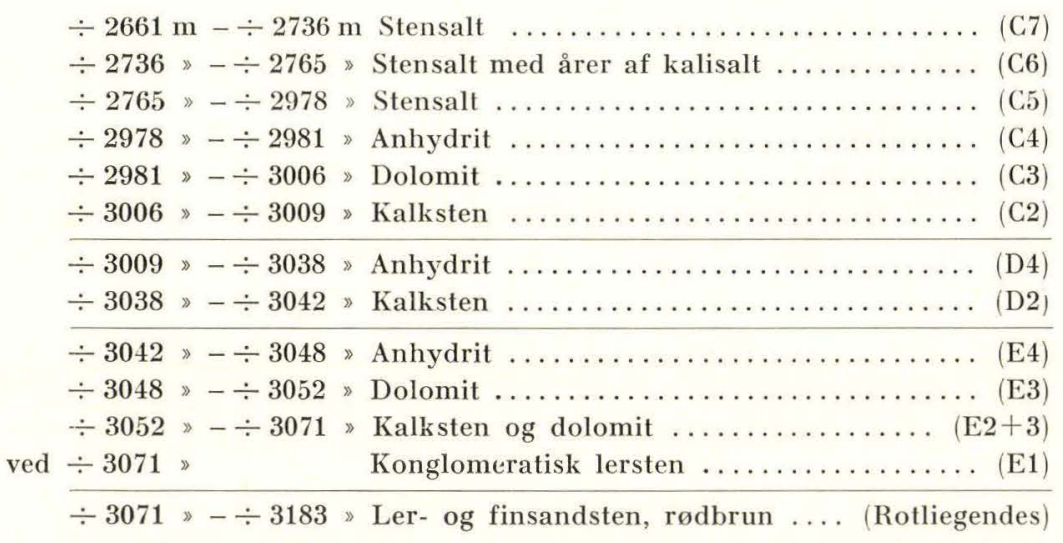

Dybtliggende Zechsteinsalt, på uforstyrret leje i 1500-3000 m dybde, er truffet ved Tønder, Hønning, Arnum, Åbenrå, R $\varnothing$ dby, Slagelse og Gassum (fig. 1).

I Salthorste, presset op lokalt under vægten af de overliggende sedimenter, er zechsteinsaltet truffet ved Harboфre, Uglev, Vejrum, Batum, M $\varnothing$ nsted, Tostrup, Hvornum og Suldrup (fig. 1). Selve saltet i disse horste dækkes altid af en »cap-rock « af gips, anhydrit, dolomit, skiferler o. a., et residuum af saltseriens bestanddele, der koncentreres ved selve saltets opløsning i det cirkulerende grundvand.

Da disse zechsteinsalte normalt ligger dybt, dækket af store sedimentmægtigheder, kan de kun konstateres med sikkerhed ved dybdeboringer. Deres tilstedeværelse røbes dog ofte ved den hyppige optræden af salt grundvand. Dette salte mineralvand vil imidlertid hos os have større udbredelse end de nævnte zechsteinsalte, da der også optræder - mere underordnede - saltlag i de aride triasaflejringer. Saltvandet i Skåne hører herhen. jvf. fig. 2. I boringen Ljunghusen hviler trias (buntsandstein) i $2150 \mathrm{~m}$ dybde direkte på silurskifer (23, s. 282); her mangler altså perm-aflejringer. 


\section{PRODUKTIONSMULIGHEDER}

Det dybtliggende zechsteinsalt har man kun ringe glæde af. Salthorstene skulle derimod kunne give mulighed for produktion af stensalt. De hidtil kendte salthorste frembyder flg. billede:

\begin{tabular}{|c|c|c|c|c|}
\hline & $\begin{array}{l}\text { Dybde til } \\
\text { cap-rock: }\end{array}$ & $\begin{array}{l}\text { Dybde til } \\
\text { salt: }\end{array}$ & $\begin{array}{l}\text { Størrelse } \\
\text { i km: }\end{array}$ & $\begin{array}{l}\text { Antal boringer } \\
\text { i salt: }\end{array}$ \\
\hline 1. Harboøre & 82 & 166 & $5 \times$ ca. 1 & 2 \\
\hline 2. Uglev $\ldots \ldots \ldots \ldots \ldots$ & 964 & 973 & & 1 \\
\hline 3. Vejrum $\ldots \ldots \ldots \ldots \ldots$ & 173 & 240 & $2 \times 3,5$ & 3 \\
\hline 4. Batum ........... & 158 & 206 & $5,5 \times 3,5$ & 13 \\
\hline 5. Mønsted .......... & 213 & 217 & & 1 \\
\hline 6. Tostrup .......... & 146 & 243 & & 2 \\
\hline 7. Hvornum $\ldots \ldots \ldots \ldots$ & 244 & 303 & $2 \times 3$ & 1 \\
\hline 8. Suldrup $\ldots \ldots \ldots \ldots$ & 103 & 200 & $5 \times 7$ & 11 \\
\hline
\end{tabular}

Der er altså rigeligt stensalt tilstede.

Kalisalte har imidlertid langt større værdi end stensalt; ifald der fandtes veludviklede kalizoner i det danske zechsteinsalt, ville det kunne give anledning til langt videregående overvejelser.

Under borearbejdet på Suldrup-horsten i 1947-48 havde DAPCo konstateret tilstedeværelsen af kalisalte $\mathrm{i}$ et par af boringerne og underkastet disse en foreløbig undersøgelse. DAPCo var dog primært interesseret i olie - ikke i særlig grad salte, hvorfor man lod spørgsmålet om udnyttelse af saltet falde.

Som ovenfor nævnt overlod DAPCo efterhånden D. G. U. et meget omfattende materiale af kærnepr $\varnothing$ ver, bl. a. saltkærnerne fra alle de på salthorstene udførte boringer. I oktober 1954 begyndte D.G. U. en systematisk gennemgang og analyse af disse saltkærner, geologisk og kemisk, og 1/12 1957 havde man analyseret $5200 \mathrm{~m}$ af de foreliggende ca. $8400 \mathrm{~m}$ saltkærne. Den 11/11 1957 kunne man tilstille Ministeriet for offentlige arbejder en foreløbig rapport over forekomsten af kalisalte i Suldruphorsten. Kalisalte forekom i DAPCo-boringerne nr. $4 \mathrm{og}$ nr. 12, mest i nr. 4, hvor der i de foreliggende kærner fandtes kalisalte i stærkt vekslende mængde flere steder, især i dybderne 527-532, 810-832 og 922-965 m (se bilag M). Indholdet af $\mathrm{K}+$ kunne stedvis stige til 10-13\%; det kunne på grundlag af analyserne bereg- 


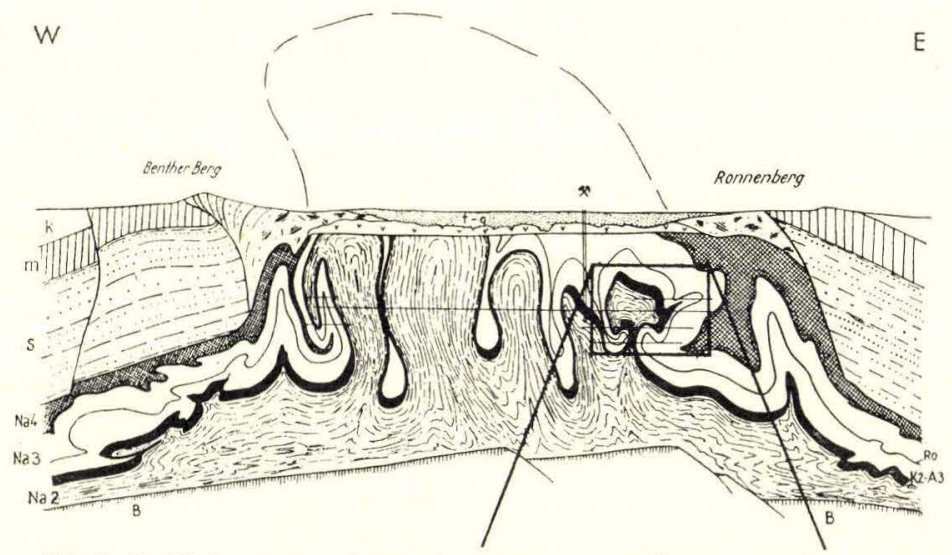

Abb. 1. Profil durch den Salzstock von Benthe im Bereich des Schachtes Ronnenberg. (Dessen Sohlen bei 560,653,750 und $850 \mathrm{~m}$ unter Tage durch horizontale Linien angedeutet.)

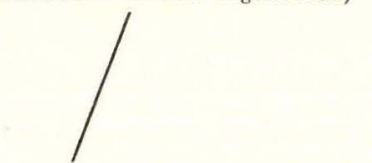

$1: 50000$
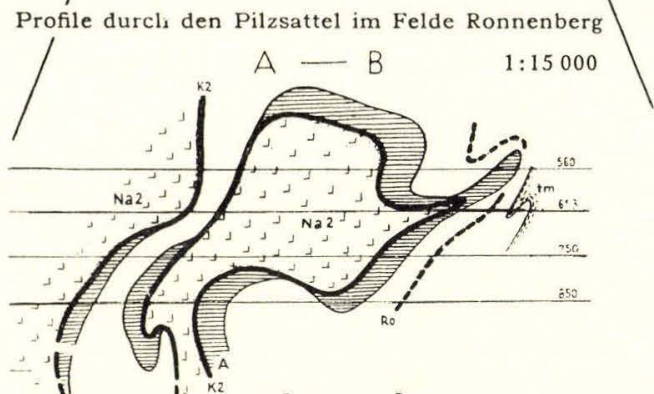

$\div$

$1 .{ }^{2} \quad C-D$
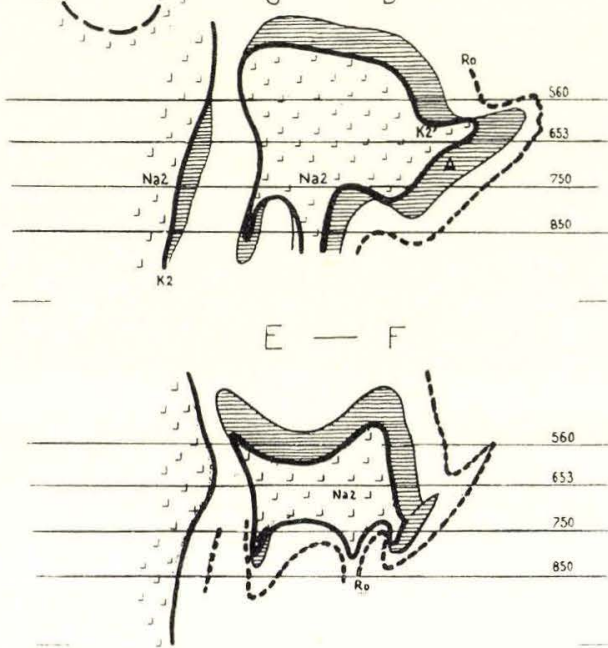

Fig. 3. Snit gennem en salthorst. Alle lag er stærkt deformerede. - G. Richter-Bernburg (her efter Saltudvalgets betænkning, s. 77). 


\section{Profil durch Bohrungen Suldrup}

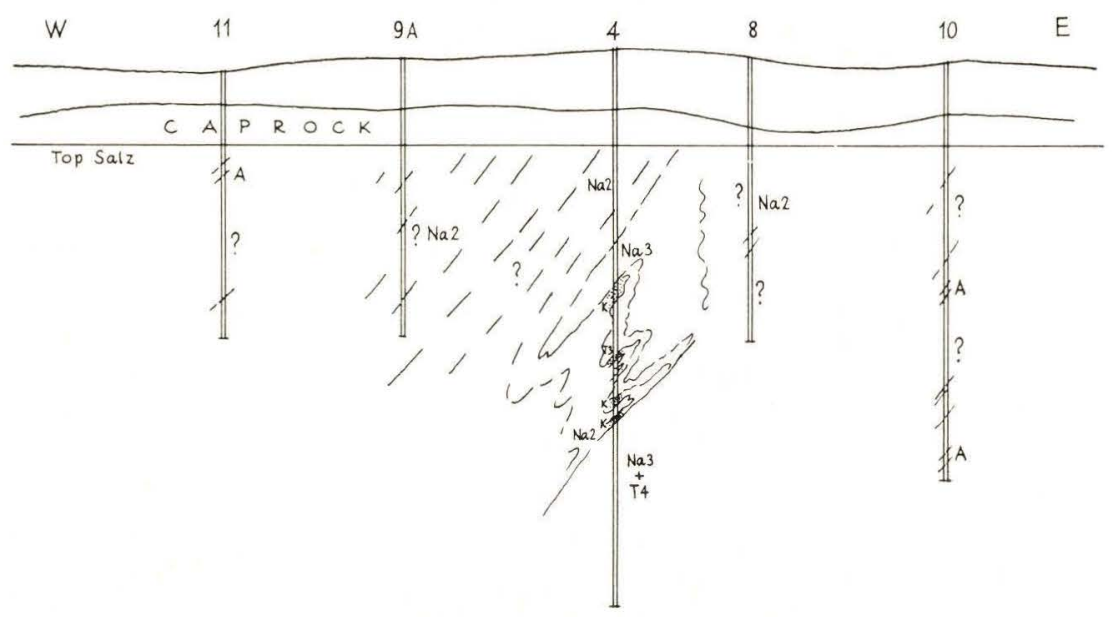

Fig. 4. Mulig fortolkning af de stærkt forstyrrede lag i boringen Suldrup 4. G. Richter-Bernburg. Efter Saltudvalgets betænkning, s. 81 .

nes, at kali hovedsagelig optrådte som hårdsalt, d. v. s. en blanding af mineralerne stensalt, kalisaltet sylvin og magniumsaltet kieserit. Som bekendt er lagene i en salthorst stærkt forstyrrede, stejltstillede og forvredne (fig. 3); det er ret sandsynligt, at det er den samme kalifl $\phi$ ts, der træffes flere gange i den samme boring i Suldrup (fig. 4).

Imidlertid var der sket en meget betydende ændring i DAPCo's koncessionsvilkår. Som nævnt s. 20 indtrådte Standard Oil 1956 som ejer af DAPCo, og i sammenhæng med dette ejerskifte udfærdigedes 13/5 1957 en ny eneretsbevilling, der bl. a. bestemte, at bevillingen omfattede kulbrinter, svovl og helium. Alle salte var altså udgået af bevillingen og overgået til statens egen disposition.

Staten $\phi$ nskede mulighederne for udnyttelse af salt og kali grundigt unders $\emptyset \mathrm{gt}$, og efter forhandlinger mellem ministeriet og АкареміEт FOR DE TEKNiske Videnskaber nedsatte A.T. V. 20/5 1958 »SALtudvalget $\ll$, med professor, dr. techn. P. SфLtoft som formand. Saltudvalget afgav en »Midlertidig rapport 27/11 1958《, hvori man tilrådede udførelse af supplerende boringer ved Suldrup, væsentlig for at fremskaffe $\emptyset$ gede og pålidelige oplysninger om kaliforekomsten. Endelig betænkning fra Saltudvalget udkom i juli 1959 (30).

Til de i den midlertidige rapport af 27/11 1958 foreslåede boringer ved Suldrup, med tilhørende bearbejdelse, stillede Egnsudviklings- 
rådet et foreløbigt beløb på 4 mill. kr. til rådighed, og til administration heraf nedsattes et særligt »BoreudvaLG « med civilingeni $\varnothing \mathrm{r}$ EINAR THORSEN som formand. Ved tillægskommissorium af $17 / 31959$ fik Saltudvalget til opgave fortsat at varetage videregående undersøgelser.

Saltudvalgets undersøgelser fastslog, at »De tilstedeværende forekomster af stensalt er af et sådant omfang, at en udtømning ikke er mulig indenfor en overskuelig årrække, og de foreliggende analyser viser en saltkvalitet, der er på linie med de udenlandske forekomster, der i dag udnyttes. - I Skandinavien fremstilles der ikke salt i industriel målestok, og da saltproduktion af transport $\varnothing$ konomiske årsager normalt foregår i nærheden af forbrugsstederne, må Skandinavien være det naturlige afsætningsområde for en dansk saltproduktion. Dette understreges af den kendsgerning, at de skandinaviske lande modtager ca. $50 \%$ af den samlede europæiske salteksport. - Der kan gennemf $\varnothing$ res en dansk produktion af såvel stensalt som af inddampningssalt. En saltmine placeres gunstigst i Batum, et inddampningssaltværk ved havn i Limfjorden eller Mariager Fjord, idet råmaterialet, en mættet saltopl $\varnothing$ sning, fremstilles ved skylleboringer i en nærliggende horst og pumpes dertil« (30 s. 35).

Den f $\varnothing$ rste saltindvinding var imidlertid allerede iværksat af $\mathrm{A} / \mathrm{S}$ »Cheminova«. På salthorsten ved Harboøre havde DAPCo i 1951 udf $\varnothing \mathbf{r t}$ en boring med følgende profil (nr. 43.19):

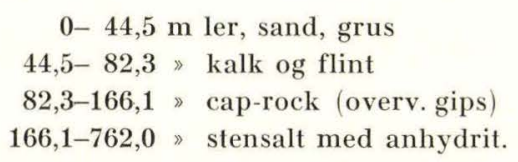

Ca. $1 \mathrm{~km} \emptyset$. herfor udførte »Cheminova« 1958 en ny boring (43.35):

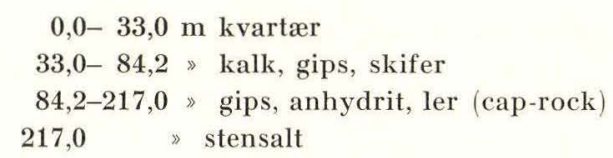

Saltproduktionen finder sted ved »opskylning《: der nedpumpes ferskvand gennem et r $\varnothing \mathbf{r}$ til saltmassen, og den mættede saltopl $\varnothing$ sning (ca. $26 \%$ ) pumpes op gennem et andet r $\varnothing \mathrm{r}$. Ved elektrolyse indvindes klor, natriumhydroxyd og restsalt i form af inddampet »vacuumsalt «. Det færdige produkt indeholder $99,4 \%$ NaCl og $0,19 \% \quad \mathrm{MgSO}_{4}$.

Om mulighederne for en dansk kaliproduktion udtaler Saltudvalget 1959: »De foreliggende kaliholdige prøver fra Suldrupforekomsten*)

*) D.v.s. de foreliggende prøver fra DAPCo's boringer 1 1947—48. 
har et kaliindhold, der er lavere, end hvad der i udlandet normalt udnyttes industrielt. - Imidlertid er det foreliggende materiale så spinkelt og behæftet med så stor usikkerhed, at det ikke er berettiget derudfra at drage konklusioner vedrørende vilkårene for indvinding af kali fra forekomsten. - Der er i Danmark et forbrug af kaligødning, der overstiger, hvad der kan forventes fremstillet fra Suldrupforekomsten. Med salgspriser, der kan forventes, viser de foretagne beregninger, at der skulle være mulighed for en rentabel produktion, hvis det tilstrækkelige kvantum er tilstede, og hvis kaliindholdet er af samme st $\varnothing$ rrelse som i de almindeligt udnyttede udenlandske forekomster (30 s. 52$)$.

Om alle de tekniske og $\varnothing$ konomiske problemer, der knytter sig til en eventuel dansk salt- og kaliproduktion, må iøvrigt henvises til Saltudvalgets betænkning af 1959 . 


\title{
LITTERATUR
}

\author{
D.G.U. = Danmarks Geologiske Undersøgelse \\ M.D.G.F. = Medd. fra Dansk Geologisk Forening
}

1. Andersen, Johs. og Hilmar Ødum: Om Forekomsten af saltforende Aflejringer i Danmarks Undergrund. - D.G.U. II. Rk. nr. 52. - 1930.

2. Andersen, Knud Hee, og Ødum, Hilmar: En Salt-Flora i Slagsmose ved Rislev. - Bot. Tidsskr. Bd. 38. - 1923.

3. Andersen, Svend: Nye Fund af Halofyter i Storebæltsområdets Indland. - Bot. Tidsskr. Bd. 41. - 1930.

4. Bredsdorff, J. H.: Geognostiske og mineralogiske Iagttagelser på en Rejse i NørreJylland. - Tidsskr. f. Natv. - 1824.

5. - Blåleret ved Odden. - smst. 1826.

6. Евеrт, A.: Magnetische Messungen im Südwestlichen Dänemark. - D.G.U. II. Rk. nr. 53. -1932 .

7. Eliassen, P., Brandorff, I. O. og Nordmann, V.: Det gamle Saltværk ved Kolding. Vejle Amts Aarbøger. 1921.

8. Forchнammer, G.: Om Danmarks geognostiske Forhold. - Tidsskr. f. Natv. - 1822.

9. - Danmarks geognostiske Forhold. - Universitetsprogram. - 1835.

10. - Om den forandrede Vandhøjde ved de danske Kyster. - Nord. Universitets Tidsskr. Kbh. 1856.

11. Gregersen, Albert og Sorgenfrei, Theodor: Efterforskningsarbejdet i Danmarks dybere undergrund. - M.D.G.F. Bd. 12, s. 141. - 1951.

12. Harte. Saltfundet ved Harte den 13. November 1936. Beretning afgivet af det af Ministeriet for offentlige Arbejder den 24. Januar 1946 nedsatte Udvalg til Revision af Undergrundslovene. - 1948.

13. Klinge, M.: Stenalderens Affaldsdynger. - Nat. Verden. 1934. S. 60.

14. Madsen, Victor: Tertiæret ved Mariager Fjord. - D.G.U. IV. Rk. Bd. 1. Nr. 8. - 1918.

15. - Hvor skal man søge efter værdifulde Raastoffer i Danmarks Undergrund? - Nat. Verden. 1931.

16. - Saltundersøgelserne ved Sønderborg og Kolding. - M.D.G.F. Bd. 8, s. 283. - 1933.

17. — Maalinger af Magnetkraftens lodrette Styrke på Fyn. - M.D.G.F. Bd. 8, s. 524. 1935 .

18. - - Hrlmar Ødum og Helge Gry: Boringer ved Langbrogaard ved Sønderborg. D.G.U. II. Rk. nr. 55. -1935 . 
19. Madsen, Victon: Maalinger af Magnetkraftens lodrette Styrke paa Lolland, Falster og Møen. - M.D.G.F. Bd. 9, s. 109. - 1936.

20. - De for Staten i 1937 udførte Tyngdemaalinger i Sønderjylland. - M.D.G.F. Bd. 9, s. 371. -1938 .

21. - Hvorledes Saltet ved Kolding blev fundet. - Nat. Verden 1938.

22. - Den magnetiske Opmaaling af Sjælland; hvorledes man for Tiden opsporer Olie. M.D.G.F. Bd. 9, s. 666. -1940 .

23. Magnusson, Lundevist och Granlund: Sveriges Geologi. - Tredie upplagen. Stockholm 1956.

24. Noe-Nygand, Arne: Det jydske grundfjeld. M.D.G.F. Bd. 12, s. 165. - 1951.

25. Nørganrd, G.: Einige Schweereverhältnisse in Dänemark. - Geodætisk Inst. Medd. Nr. 12. -1939 .

26. Nørlund, N. E. og Brockamp, B.: Seismische Feldarbeiten in Dänemark. I. Teil. Geodætisk Institut 1934.

27. Nørvang, Arsel: The Foraminifera of the Lias Series in Jutland, Denmark. - M.D.G.F. Bd. 13, s. 275 . -1957.

28. Pingel, C.: Om Diluviet og Alluviet i det nordlige Jylland. - Tidsskr. f. Natv. 1828.

29. Rosenkrantz, Alfred: Undergrundens tektoniske Forhold i København og nærmeste Omegn. - M.D.G.F. Bd. 6, Nr. 26. - 1925.

30. Saltudvalget. Betænkning. - A.T.V. Beretning Nr. 35. 1959.

31. Sorgenfrei, Theodor: Perm-systemet i det sydlige Danmark. - M.D.G.F. Bd. 13, s. $263 .-1957$.

32. - Dybgrundens geologi. - Trap. Danmark. Bd. 1. - 1958.

33. Steenstrup, P.: Tvende Spørgsmaal med Svar. - Mag. for Kunstnere og Haandværkere. - 1829,

34. Ussing, N. V.: Danmarks Geologi. - D.G.U. III Rk. Nr. 2. - 1899.

35. Wolff, W.: Gemeinsame Probleme der geologischen Landesforschung von Dänemark und Deutschland. - D.G.U. Compte Rendu de la Réunion Géol. Internat. 1928.

36. Øрum, Hılmar: Studier over Daniet i Jylland og på Fyn. - D.G.U. II. Rk. Nr. 45. - 1926.

37. - Saltforekomster i den danske undergrund og mulighederne for udnyttelse heraf. - Ingeniør- og Bygningsvæsen. Nr. 24. - 1957.

38. Ødum, Hilmar og Christensen, Werner: Danske Grundvandstyper og deres geologiske optræden. - D.G.U. III Rk. Nr. 26. - 1936.

39. Dinesen, ARne: Dybdeboringer på Sjælland. Lavø nr. 1. - M. D. G. F. Bd. 14, s. $280-1960$.

40. Larsen, Gunnar og Buch, Arne: Dybdeboringer på Sjælland. Slagelse nr, 1. - M. D. G. F. Bd. 14 , s. $281 .-1960$. 


\section{B I LA G}

Til Handelsministeren.

Bilag A.

Undertegnede Ingeniør, cand. polyt. Valdemar Olsen og Assistent ved Danmarks geologiske Undersøgelse Hilmar Ødum tillader os herved at fremføre følgende Sag for Deres Excellence.

For nogen Tid siden blev vi opmærksom paa en ejendommelig Saltvandsforekomst ved Byen Rislev, 6 km N.f. Næstved. Vi har foretaget en foreløbig geologisk og kemisk Undersøgelse, der har givet det vigtige Resultat, at Saltvandet hidrører fra dybere liggende Dannelser og har en lignende Sammensætning som det, der træffes ved de tyske "Saltzstellen (Kogsalt med Kali, Magnium m.m.). Vi agter nu at forsøge at fremskaffe de fornødne Midler til en videregaaende Undersøgelse, som skulde klarlægge de geologiske og kemiske Forhold og afgøre Spørgsmaalet, om der her i Landet findes Saltlejer (Stensalt, evt.m. Kali) liggende i en saadan Dybde, at en industriel Udnyttelse deraf er mulig.

Da Sagen imidlertid ved Forsøg paa at fremskaffe de fornødne Midler ikke længere kan hemmeligholdes, og da der ikke her i Landet findes nogen Bjergværkslovgivning, saaledes at vor Ret som Findere beskyttes, tillader vi os at henvende os til Deres Excellence med Anmodning om, at der maa tildeles os en Prioritet paa vort Fund, f. Eks. i Form af en Koncession til indenfor et begrænset Aaremaal at foretage Dybdeboringer i Landsdelene Ø.f. Storebælt til Opsøgelse af Saltforekomster (og eventuelt Olieforekomster), og en Koncession paa Udnyttelsen af eventuelle Forekomster imod en passende Afgift til Staten, alt fastsat efter nærmere Forhandling med det høje Ministerium.

Vi tillader os iøvrigt at henvise til vedlagte Erklaring fra Direktøren for Danmarks geologiske Undersøgelse, Herr Statsgeolog, Dr. phil. V. Madsen.

(sign.) Hilmar A. Ødum.

København, 22. Januar 1923.

\section{Underdanigst}

(sign.) Valdemar H. G. Olsen.

Handelsmin. 1923 J. Nr. 156 Bil. 127/123. ad L. J. 1923 Nr. 2060.
DANMARKS GEOLOGISKE UNDERSØGELSE

14 Gammelmønt, Kjøbenhavn K., d. 27/1.1923.

Til Handelsministeriet.
Bilag B.

Handelsmin. J. Nr. $156^{103}$

1923

27. Januar 1935.

I Anledning af det medfølgende Andragende fra Ingeniør, cand. polyt. Valdemar Olsen og Assistent ved Danmarks geologiske Undersøgelse Hilmar Ødum om at faa 
meddelt Koncession paa at foretage Dybdeboringer efter Saltforekomster (og eventuelt Olieforekomster) i Landsdelene Øst for Storebelt, tillader jeg mig at fremkomme med følgende:

I Tyskland udvindes der industrielt i betydelig Udstrækning Kalisalte og Kogsalt (og ogsaa en Del Petroleum) af forskellige Saltlejer. De Saltlejer, som findes nærmest ved Danmark, er beliggende mellem Heide og Hemmingstedt, ved Lieth (ved Altona) og ved Segeberg i Holsten, ved Lübtheen i Mecklenburg, ved Sperenberg og Rüdersdorf ved Berlin og ved Inowrazlau i Posen. Et betydeligt Antal Saltkilder, som optræder nordpaa lige til Østersøens Kyst i Mecklenburg og Pommern, tyder dog paa, at der findes Saltlejer mindst lige saa langt mod Nord.

Det er derfor ingenlunde umuligt, at Saltvandsforekomsten ved Rislev stammer fra et dybtliggende Saltleje, hvilket den allerede foretagne Undersøgelse forøvrigt tyder paa, og da der endnu ikke er fundet Saltlejer i Danmark, fortjener Forekomsten ved Rislev i høj Grad en Undersøgelse saavel fra et videnskabeligt som fra et praktisk Synspunkt.

Da imidlertid Udgiften ved en saadan Undersøgelse er meget betydelig, og Sikkerheden for, at den kan betale sig i praktisk Henseende, kun er ringe, bør Statens under den øjeblikkelige vanskelige finansielle Situation formentlig ikke foretage denne Undersøgelse, men den bør overlades til Private. Jeg tillader mig derfor at anbefale, at der tilstaas d'Herrer Olsen og Ødum den Koncession, som de ansøger om, dog saaledes, at den bortfalder i Løbet af nogle Aar, hvis Boringerne ikke giver det ønskede Resultat, og at Staten sikrer sig Andel i det eventuelle Udbytte.

(sign.) Victor Madsen.

LANDBRUGSMINISTERIET

(Landvæsenskontoret)

Kobenhavn, den 11. September 1923.
Bilag C.

L. Journal $1923 \mathrm{Nr} .2060^{2}$ Brev Nr. $11258-59$.

gf.

I et til Handelsministeriet stilet, af nævnte Ministerium hertil oversendt Andragende af 22. Januar d. A. har Hr. Ingeniøren i Forening med Assistent ved Danmarks geologiske Undersøgelser Hilmar Ødum anholdt om, at der maa blive meddelt Dem og Deres Medandrager Enerets-Bevilling til indenfor et begrænset Aaremaal at foretage Dybdeboringer i Landsdelene øst for Storebælt til Opsøgelse af Saltforekomster (og eventuelt Olieforekomster) samt eventuelt til Udnyttelsen af saadanne Forekomster af Salt og Olie.

Efter at man i den Anledning har brevvekslet med Undervisningsministeriet skal man til Efterretning tjenstlig meddele, at Ministeriet savner Hjemmel til at bevilge det ansøgte, og at man derfor ikke vil kunne foretage videre i Sagen.

$$
\text { (sign.) Madsen-Mygdal. / (sign.) H. Larsen. }
$$

Hr. Ingeniør cand. polyt. Valdemar Olsen,

Nansensgade $75 \mathrm{~A}$.

\section{DANMARKS GEOLOGISKE UNDERSØGELSE}

Bilag D.

Til Statsministeriet.

27. Oktober 1931.

I den senere Tid er der opstaaet en levende Interesse for Spørgsmaalet, om der i Danmarks Undergrund findes værdifulde Raastoffer, saasom Petroleum, Kalisalte, Stenkul og Malme, og hvor man eventuelt skal søge efter dem. 
For at forberede en Undersøgelse af dette Spørgsmaal har Danmarks geologiske Undersøgelse foretaget Maalinger af Magnetkraftens Vertikalintensitet over et Omraade, som strækker sig fra Rigsgrænsen mod Nord til Linien Varde-Vejle og mod Øst over det vestlige Fyn til Linien Faaborg-Odense-Bogense.

Hvor Magnetkraften er større end normalt, maa dette hidrøre fra, at Grundfjældet, som kan indeholde jernholdige, magnetiske Stenarter, naar forholdsvis højt op, og Formaalet med de magnetiske Maalinger var netop at finde det Sted, hvor Magnetkraften er størst, for dér naar Grundfjældet højst op, og der vil det altsaa blive billigst at foretage en Dybdeboring ned til det. En saadan Boring vil give Oplysning om, hvilke geologiske Formationer, der findes mellem Skrivekridtet og Grundfjældet, og særlig om de Formationer, som kan indeholde værdifulde Raastoffer, Permformationen og Kulformationen, findes hos os.

De magnetiske Maalinger gav det Resultat, at den stærkeste Magnetkraft findes c. $4.5 \mathrm{~km} \mathrm{NNV}$ for Kolding, $2 \mathrm{~km}$ Nord for Landsbyen Harte, og her vil det altsaa være billigst at foretage en Dybdeboring ned til Grundfjældet.

Da Mangelen af en Lovgivning paa dette Omraade er en væsentlig Hindring for Tilvejebringelsen af den nødvendige Kapital til Efterforskningen og eventuelt Udnyttelsen af værdifulde Raastoffer i Danmarks Undergrund, og da det formentlig er i Samfundets Interesse, at en saadan Efterforskning bliver iværksat, tillader jeg mig at andrage Statsministeriet om, at det vil lade udarbejde et Lovforslag om Efterforskningen og Udnyttelsen af værdifulde Raastoffer i Danmarks Undergrund og forelægge det til Vedtagelse i Rigsdagen.

En saadan Lov bør formentlig først og fremmest sikre Staten Ejendomsretten til disse Raastoffer. Da ingen Grundejer har købt sin Ejendom under den Forudsætning, at der i Undergrunden findes værdifulde Raastoffer, krænkes ingen berettigede Interesser ved en saadan Lovbestemmelse.

Loven bør endvidere indeholde Bestemmelser om, hvorledes Staten selv kan undersøge, om der findes saadanne Raastoffer, og udnytte dem, hvis de findes, eller hvis det foretrækkes, give et Selskab gennem en Koncession Eneret til en saadan Efterforskning og Udnyttelse indenfor et bestemt Omraade eller Landsdel eller over det hele Land, mod en passende Afgift.

Loven bør endvidere, i Lighed med den nævnte Lov om Vandforsyningsanlægs § 1 , sidste Stykke, indeholder en Bestemmelse om, at enhver, der udfører en Dybdeboring, til Danmarks geologiske Undersøgelse skal indsende en meddelelse om Boringens Beliggenhed, om de gennemborede Jord- eller Stenlags Tykkelse og Beskaffenhed, om de fundne Raastoffer, samt Prøver af Jord- og Stenlagene og af Raastofferne. Meddelelsen om Boringen bør indsendes, saasnart den er paabegyndt, saa at Danmarks geologiske Undersøgelse kan øve Kontrol med Boringen under dennes Udførelse.

Endnu skal jeg tilføje, at hvis Staten vil sikre sig Kontrol med og en passende Afgift af, hvad der maatte findes i Danmarks Undergrund af værdifulde Raastoffer, bør den nævnte Lovgivning ske saa hurtigt som muligt. Jeg har nemlig bragt i Erfaring, at et tysk Selskab i den nærmeste Fremtid vil foretage en Boring ved Sønderborg paa Vestsiden af Alssund efter Stensalt og Kalisalte og anlægge en Fabrik til Udnyttelse af dem.

(sign.) Victor Madsen. 
Til Direktøren for Danmarks geologiske Undersøgelser.

Under Henvisning til Danmarks geologiske Undersøgelsers Skrivelse af 27. f. M. (Nr. 65) angaaende Spørgsmaalet om Udarbejdelse af et Lovforslag angaaende Efterforskning efter og Udnyttelse af de værdifulde Raastoffer, som maatte findes i Danmarks Undergrund, skal jeg herved meddele, at det efter Behandling af Sagen i et Ministermøde af Statsministeren er paalagt mig at udarbejde et Lovforslag. Et foreløbigt Udkast til et saadant Lovforslag vedlægges herved.

Jeg beder mig meddelt, hvilke Bemærkninger Hr. Direktøren kunde ønske at knytte til Udkastet, eventuelt om De kunde ønske narmere Forhandling med mig

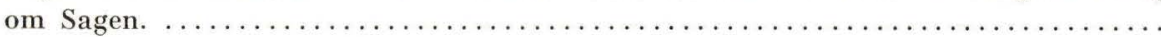

(sign.) Frederik V. Petersen.

Af Seismos' Beretning:

Bilag F.

Det andet Sted, hvor man har boret ned i Skrivekridtets Underlag, ligger c. $150 \mathrm{~km}$ S. f. Kolding ved Heide i Holsten. Her fandtes under Skrivekridtets Underlag dybere Øvre Kridts Kridtkalksten, som underlejres af en rød Lagrække, der er henført til Permformationen. Skrivekridtet har her en Tykkelse af indtil $500 \mathrm{~m}$. De røde Aflejringer er Dolomiter, Mergel og Lerskifere.

Paa Grundlag af det seismiske Materiale er det ikke muligt at afgøre, om $3900 \mathrm{~m} / \mathrm{s}$ Laget svarer til de senone Lag, som er fundne under Skrivekridtet i Boringen i København, eller til de røde Permlag ved Heide. Efter dets seismiske Karakter kan det svare til begge, da disse to Slags Aflejringer ligner hinanden i deres petrografiske Beskaffenhed. Efter de nyere Arbejder at dømme er det sandsynligt, at Permformationen optræder i Jyllands Undergrund.

Zonerne med storre Hastighed fortjener en nærmere Omtale. Det er de Steder paa Løbetidskurverne, hvor der indenfor 3900 m's Horizonten findes Angivelser af særlig store Hastigheder, hvis Optræden i Løbetidskurverne dog er temmelig uregelmæssig. Tydningen af disse Zoner maa behandles med den største Forsigtighed, da de optræder uregelmæssigt, og da man ikke har Klarhed over det dybe seismiske Lags geologiske Forhold. Principielt kan saadanne store Hastigheder faktisk hidrøre fra den dybe Undergrund, og de kan skyldes haarde Kalksten, Gibs, Salt o. I., af ringe Udstrækning. Paa den anden Side kan ogsaa smaa tektoniske Forskydninger i en forholdsvis ensartet Lagrække, som smaa Flager, Trappebrud o. l. bevirke, at der optræder store Hastigheder i Løbetidskurverne. $\ldots \ldots \ldots \ldots \ldots \ldots \ldots \ldots \ldots \ldots$

Lejringsforholdene. Saavel af Løbetidskurverne som af den omtalte ensartede Dybde, Skrivekridtets Overflade har, og af Dybdeangivelserne for $3900 \mathrm{~m} / \mathrm{s}$ Laget maa man slutte, at der i det undersøgte Omraade ikke findes nogen Saltdome lignende Struktur af nordisk Type, der som en Oppresningsdome er trængt op igennem $3900 \mathrm{~m} / \mathrm{s}$ Laget og op i $2400 \mathrm{~m} / \mathrm{s}$ Laget.

Naar man vil tyde de omtalte store Hastighedsangivelser delvis som Saltforekomster omtrent i Niveau med $3900 \mathrm{~m} / \mathrm{s}$ Laget, saa bliver det kun lokale Forekomster, der er for ubetydelige til, at det kan lønne sig at udnytte dem. Indenfor en Dybde af c. $1000 \mathrm{~m}$ kan man ikke vente, at der findes nogen kompakt, tykkere Saltmasse,

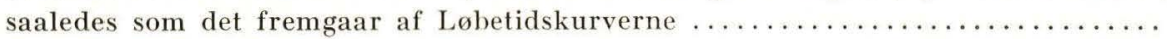


Resumé af Resultaterne. Følgende maa fremhæves:

En Saltdome af den nordtyske Type er ikke fundet i Undersøgningsomraadet. Det som Skrivekridt tydede $2400 \mathrm{~m} / \mathrm{s}$ Lags Overflade ligger alle Vegne i omtrent samme Dybde.

Det i en Dybde af c. $700 \mathrm{~m}$ fundne $3900 \mathrm{~m} / \mathrm{s}$ Lags geologiske Natur maa staa hen. Det samme gælder for Zonerne med endnu større Hastighed.

$3900 \mathrm{~m} / \mathrm{s}$ Lagets Dybde er jævnt stigende fra Nord mod Syd. I den centrale Del af Omraadet er det svagt ophvælvet.

Oversat af V.M.

Bilag G.

Gutachtlicher Bericht über die seismischen Untersuchungen nordwestlich Kolding (Dänemark).

Baade $2400 \mathrm{~m} / \mathrm{s}$ Aflejringen og $2700 \mathrm{~m} / \mathrm{s}$ Aflejringen ligger gennemgaaende vandret. De ganske smaa Forandringer i Højderne falder indenfor Fremgangsmaadens Nøjagtighedsgrænse. Intetsteds er der fundet noget, som tyder paa, at Aflejringerne har været Genstand for større Forstyrrelser eller Flageforskydninger. Der er tværtimod paavist, at disse Aflejringer, som har en Tykkelse af omtrent $500 \mathrm{~m}$, ligger absolut uforstyrret.

Den derunder, i en Dybde af $700 \mathrm{~m}$ under NN følgende seismiske Horisont er i fysisk Henseende ganske forskellig fra de overliggende Aflejringer. Ikke blot er Hastigheden væsentlig større - i Gennemsnit $3900 \mathrm{~m} / \mathrm{s}$. - men den ændrer sig paa korte Afstande meget betydeligt, saa at den kan blive en $1000 \mathrm{~m} / \mathrm{s}$ større eller mindre.

Denne Egenskab er udpræget i alle Profilerne. Det kan skyldes, at Horisonten har en overordentlig ujævn Overflade, at Aflejringen har en meget vekslende petrografisk Beskaffenhed, og at der i den findes Indlejringer af uregelmassige fastere Partier.

Man kan næppe antage, at den petrografiske Beskaffenhed i det undersøgte Omraade stadigvæk veksler, snarere maa man formode, at de ringere Hastigheder skyldes Ujævnheder i Aflejringens Overflade, at der findes lokale Udvaskninger, Lavninger eller Dale, udfyldte med mindre elastisk Materiale fra de højere liggende Aflejringer. De større Hastigheder kan ogsaa skyldes, at Aflejringen lokalt rager op eller er presset op i den overliggende Aflejring, eller at der findes Indlejringer af mere elastiske Partier i den. Dette Forhold er truffet forskellige Steder i Nordtyskland, hvor man i Senonet (i det øvre Kridt) seismisk og ved Boringer har paavist linseformige Aflejringer, som lokalt fik Hastigheden til at stige til $5000 \mathrm{~m} / \mathrm{s}$. Naar man drager en Sammenligning med Carlsbergfondets Dybdeboring i København, maa man regne med, at dens Overflade maaske lokalt ikke er saa jævn som de højere liggende Aflejringers Overflade.

Man kan dog ikke afvise den af Seismos anførte Mulighed, at Aflejringen ikke nødvendigvis maa høre til Senonet, men at den kan bestaa af de røde Aflejringer, som man har truffet i Boringerne ved Heide i Holsten og som man har henført til Permformationen.

Af Antagelsen, at $3900 \mathrm{~m} / \mathrm{s}$ Aflejringen bestaar af Dolomiter, Lerskifere og Mergellag ligesom ved Heide, følger imidlertid, at den Del af Kridtformationen, som ligger under Skrivekridtet, maa mangle over hele det undersøgte Omraade, og det er ikke sandsynligt. Men lokalt kan disse røde Lag være hvælvet op eller presset op i Senonet. Hastighedsvekslingerne kan saaledes ogsaa forklares ved, at den dybe Undergrund har en saadan indviklet Bygning. 
Denne Aflejring, som er saa vanskelig at identificere, ligger gennemsnitlig i en Dybde af 700-800 m. Den ligger dog ikke vandret, men hæver sig sydpaa. I det nordligste Profil VI ligger den i en Dybde af 750-800 m under Havfladen. I denne Dybde holder den sig til Stallerup Sø, men derpaa stiger den jævnt til $700 \mathrm{~m}$ og længst mod Syd i Profil VII endog til $650 \mathrm{~m}$ under Havfladen.

Denne Stigning staar sikkert i Forbindelse med det her begyndende gravimetriske Højdeomraade, som er paavist ved Pendulmaalingerne.

Man kan heraf drage den geologiske Slutning, at en fortsat Opsporing af Salthorste bør forlægges langere mod Syd, nærmere hen imod Flankeregionen af det gravimetriske Højdeomraade, da man her kan regne med, baade at de dybere Aflejringer naar højere op mod Overfladen, og at der findes større Brudzoner, som jo er af væsentlig Betydning for Fremkomsten af Salthorste.

I $3900 \mathrm{~m} / \mathrm{s}$ Zonerne i Løbetidskurverne forekommer der endvidere korte Partier, som viser en endnu større Hastighed, indtil over $5000 \mathrm{~m} / \mathrm{s}$. Disse større Hastigheder er imidlertid stedse baseret paa et eller i det højeste to Iagttagelsespunkter, saa at man ikke med Sikkerhed kan se, om der virkelig findes Partier med større Hastighed, eller om denne kun er tilsyneladende. Saadanne tilsyneladende større Hastigheder kan skyldes:

1) en petrografisk anderledes beskaffen Aflejring.

2) tektoniske Forskydninger i $3900 \mathrm{~m} / \mathrm{s}$ Aflejringen.

3) haarde Indlejringer.

I hvert Tilfælde er de uregelmassige og smaa Omraader med de store Hastigheder af for ringe Udstrækning til, at disse Hastigheder kan skyldes Saltdomer. I hele det undersøgte Omraade er der ikke fundet noget som helst, som tyder paa Tilstedeværelsen af Saltdomer.

Berlin d. 11. Jan. 1935.

O. Barsch.

Oversat af V. M.

\section{DANMARKS GEOLOGISKE UNDERSOGELSE}

Bilag $\mathrm{H}$.

Til statsministeriet.

17. Januar 1935.

Med min Skrivelse Nr. 153 af 8. Okt. 1934 indsendte jeg til Statsministeriet et Exemplar af Indberetningen fra Selskabet Seismos om de seismiske Undersøgelser ved Kolding i 1934. Et andet Exemplar blev sendt direkte til Professor O. Barsch ved den preussiske geologiske Landesanstalt i Berlin til kritisk Gennemgang, og efter nu at have modtaget hans "Gutachtlicher Bericht" om den, skal jeg hermed indsende en Afskrift af den. I den første Del af den, som indeholder Beskrivelsen af de enkelte Profiler, og som kun har væsentlig Interesse for Specialisterne, er det tyske Sprog bibeholdt. Den anden Del, Bedømmelsen af Resultaterne, som har mere almindelig Interesse, har jeg oversat paa Dansk. Originalen vil jeg gerne opbevare i Danmarks geologiske Undersøgelses Arkiv. Tillige indsender jeg en dansk Oversxttelse af det sidste Afsnit i Indberetningen fra Seismos, Geologisk Tydning af Maaleresultaterne, hvilket er det Afsnit, som har størst almindelig Interesse.

Hertil skal jeg knytte følgende Bemærkninger:

De af Seismos foretagne Undersøgelser i Kolding Egnen er utvivlsomt udførte med stor Omhu, Nøjagtighed og Hurtighed. Professor Barsch anfører da ogsaa i sin Indledning, at hans Gennemgang af Seismogrammerne og Løbetidskurverne har vist ham, at Seismos har lagt Vægt paa kun at benytte de Indsatser i Seismogrammerne, som der ingensomhelst Indvending kan gøres imod, saaledes at der foreligger 
et ganske ulasteligt Materiale, og i Seismos' Udnyttelse af det er der ikke fundet nogensomhelst Fejl.

Beskrivelserne af Profilerne giver mig ikke Anledning til at gøre Bemærkninger, og det samme gælder de Afsnit i Seismos' geologiske Tydning af Maaleresultaterne og i Barsch's Bedømmelse af Resultaterne, som omhandler Istidsdannelserne, Tertiæret og Skrivekridtet. Om disse bør det dog nævnes, at de indeholder en Fylde af Iagttagelser og Bemærkninger om disse, som er af stor videnskabelig Interesse, og som vil være til god Nytte ved fremtidige seismiske Undersøgelser. Det samme gælder de Afsnit, der omhandler den Aflejring, som ligger under Skrivekridtet, og som af Seismos kaldes $3900 \mathrm{~m} / \mathrm{sek}$. Laget. Ved Bedømmelsen af denne Aflejring savner man i høj Grad, at der endnu ikke er foretaget nogen virkelig Dybdeboring i Danmark. De Dybdeboringer, som ligger nærmest ved Kolding, i en Afstand af c. $150 \mathrm{~km}$, er de mellem Heide og Hemmingstedt i Holsten udførte Dybdeboringer efter Olie, af hvilke den dybeste standsede ved $1664 \mathrm{~m}$. I denne naaede man gennem Skrivekridtet ved $472 \mathrm{~m}, \mathrm{og}$ man kom derefter ned i en Lagrække, bestaaende af graa, røde og blaa Lerlag, og derunder røde Lerlag, Lerskifere og Salt. Ved en anden Dybdeboring til $1052 \mathrm{~m}$ naaede man gennem Kridtet ved $447 \mathrm{~m}$ og kom ned i lignende røde Lag. De tyske Sagkyndige har henført den overste, lidet tykke Del af Lagene under Skrivekridtet til det saakaldte Øvre Gault (den øverste Del af det nedre Parti af Kridtformationen) og Resten til Permformationen. Denne bestaar her af Dolomit (magnesiaholdig Mergel) og Lerskifere. Fra en Boring til $814 \mathrm{~m}$ forelaa der Borekærner, som er undersøgte af C. Gagel. I denne Boring fandtes der under Skrivekridtet $95 \mathrm{~m}$ Turon: Kridtkalk, Kridt, haard Kalksten, Mergelkalk, og $60 \mathrm{~m}$ Cenoman: Mergel, Mergelkalk, Kridtkalk. (Turon og Cenoman er Underafdelinger af Kridtformationen, Turonet findes umiddelbart under Skrivekridtet, Cenomanet umiddelbart under Turonet).

Det forekommer mig, at disse meget vexlende, mere eller mindre faste Lag svarer godt nok til den Aflejring, som ved Kolding ligger under Skrivekridtet, saaledes som den giver sig til Kende i sine seismiske Forhold, at Seismos er rigelig forsigtig og Barsch endnu mere forsigtig i sine Udtalelser om denne Aflejring, saa meget mere, som Permformationen nu er fundet paa Halvøen Eiderstedt i Slesvig og paavist ved Oslo Fjord i Norge, og de fleste danske Geologer mener, at Permformationen findes under Kridtformationen i hele Danmark (undtagen Bornholm), ja, nogle af de svenske Geologer anser det endog for rimeligt, at den ogsaa findes i det sydvestlige Skaane.

Hertil kommer, at Piepmeyer \& Co., som foretog de seismiske Undersøgelser ved Kolding i 1933, i sin Beretning til Kolding Selskabet, der lod Undersøgelserne foretage, siger om den fundne Saltforekomst ved Paaby: "I dette Profil fandtes mellem Seismograferne et Materiale, som i Seismogrammerne viste de for Salt karakteristiske Egenskaber, altsaa en kort Periode med ringe Amplitude (Salttakker), saa vel som en for Salt typisk Klangfarvning af Knaldet. - I et Brev til mig udtaler Ingeniør Kurz, der ledede Piepmeyers Undersøgelser: »Disse Salttakker er ved vor Instrumentjustering en for Salt typisk Periode. Men for at udelukke Fejltydning maa man samtidig med denne Periode have den for Salt karakteristiske Hastighed. Som De ved, ligger den ved $5000 \mathrm{~m} / \mathrm{sek}$.

Piepmeyer \& Co. er et Selskab, som i Anseelse ikke staar tilbage for Seismos, og de vilde ikke udtale sig saaledes, hvis de ikke kunde vedstaa det. Hertil kommer, at Piepmeyers Folk arbejdede med finere Seismografer end Seismos, og Piepmeyers Seismografer forstørrede Svingningerne mere end Seismos'. Salttakker vilde ikke træde frem i Seismos' Seismogrammer som i Piepmeyers. For mig er der ingen 
Tvivl om, at den øvre Del af $3900 \mathrm{~m} / \mathrm{s}$ Laget ved Kolding skal henføres til Turon, Cenoman og Gault, og den nedre Del til Permformationen, ligesom ved Heide, og at der virkelig findes Salt dèr, hvor der er fundet en Hastighed af $5000 \mathrm{~m} / \mathrm{s}$, men desværre er der ingen Saltdomer fundet i det undersøgte Omraade. .............

(sign.) Victor Madsen.

Bilag I.

Kabenhavn, d. 3. August 1934.

Jeg undertegnede Fred. F. Ravlin af Miami Florida U. S. of Amerika; President for "The East coast oil and natural gas Cy. Inc", og Appreciurer for "The Federal Land Bank i Columbia, Syd Carolina, U.S.A., ansøger herved høfligst den danske Regering om Koncession til at bore efter Olie i Danmark.

Jeg erklærer mig i Stand til, at have alt i Orden og paabegyndt den første Boring inden 2 (to) Aar fra Dato, og selv at afholde alle Udgifter, i modsat Fald tilbagegives Koncessionen.

Jeg kan tilbyde den danske Stat 4 (fire) procent af den udvundne Olie i den Form, den maatte ønskes, som Afgift for Koncessionen.

Min Garanti for, at jeg kan magte Opgaven, er at jeg er en af de mest benyttede Olieexperter i U.S. A. og lige har fuldført og financieret Olieboringerne i Syd Florida; disse er 5400' dybe og kostede $\$ 150.000$ pr. Boring.

Som Reference kan opgives den amerikanske Gesandt i København, hendes Excellence Mrs. Ruth Bryan Owen, der er nær knyttet til min Familie og derfor kan give

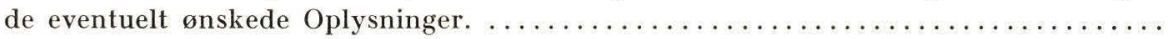

Med særdeles Højagtelse

(sign.) Fred F. Ravlin.

STATSMINISTERIET

Bilag J.

København, den 28. September 1934.

Statsministeriet har i Dag tilskrevet Fred F. Ravlin, Miami, Florida, saaledes:

»I Skrivelse af 3. f. M. har De anholdt om Tilladelse til at bore efter Olie i Danmark.

I denne Anledning skal man næst at oplyse, at der dels i afvigte, dels i indeværende Aar saavel af private som af Staten har været foretaget seismiske Undersøgelser af Undergrunden i Egne nær ved Kolding By, herved meddele følgende:

Under Forudsætning af fornødent Samtykke fra Ejerne af de paagældende Grunde meddeler Ministeriet herved den ønskede Tilladelse til Boringer over et Terræn omkring Kolding By indenfor en Afstand af $50 \mathrm{~km}$. i hver Retning paa følgende Vilkaar:

Forsaavidt de foran stillede Betingelser overholdes, forpligter Ministeriet sig til indenfor det næunte Tidsrum af 2 Aar ikke at meddele andre Tilladelse til at foretage Dybde-Boringer efter Raastoffer indenfor det nævnte Terræn.

Den foran meddelte Tilladelse omfatter ikke Ret til Indvinding af værdifulde Raastoffer; men forsaavidt der maatte blive Spørgsmaal herom, maa dette være Genstand for en fornyet nærmere Forhandling med Ministeriet, hvorunder der tillige 
vil blive Spørgsmaal om passende Godtgørelse for den af Staten og af private anvendte Bekostning ved Foretagelsen af de foran nævnte seismiske Undersøgelser ved Kolding.

Hvilket herved meddeles.

P. M. V.

Danmarks geologiske Undersøgelse.

(sign.) Frederik V. Petersen.

\section{OVERENSKOMST}

Bilag K.

Den danske Statsminister ....... og Danish American Prospecting Co. (herefter kaldet Selskabet) med Tiltrædelse fra Gulf Refining Company ....... har truffet følgende Overenskomst:

Punkt I. - Den af Ministeren til Selskabet under 7. Februar 1938 udstedte Eneretsbevilling ændres herved som følger:

(A) Følgende føjes til $\S 4$ i Eneretsbevillingen:

»(a). Parterne er i Princippet enige om, at det Samarbejde, der allerede er etableret mellem Danish American Prospecting Co. og de danske videnskabelige Institutioner (Geodætisk Institut, Danmarks geologiske Undersøgelse og Meteorologisk Institut), skal fortsættes, og Omraadet for det udvides. Om ethvert videnskabeligt Arbejde, der udføres af et af Instituterne paa Selskabets Opfordring, og om den Betaling, der eventuelt skal erlægges af Selskabet derfor, træffes i hvert enkelt Tilfælde Aftale mellem Selskabet og vedkommende Institut.

(b). Skulde nogen af de af Staten foretagne Undersøgelser føre til praktiske Resultater, d. v. s. til Opdagelsen af Raastoffer i Undergrunden eller til Oplysninger angaaende Undergrundsforhold, som maatte være af Værdi for Selskabet, vil saadanne Resultater omgaaende blive meddelt til Selskabet, og Selskabet vil da, saafremt Betaling skal erlægges, betale Staten det Beløb, som efter Selskabets Mening repræsenterer den fair Værdi for Selskabet af de paagældende Resultater eller Oplysninger."

(B) Følgende føjes' til § 5 i Eneretsbevillingen:

"Alle Prøver af Lag, der er blevet gennemboret, alle geologiske Forsteninger og alle Dele af Kærner, der skal leveres til Danmarks Geologiske Undersøgelse, skal opbevares af Danmarks Geologiske Undersøgelse i det mindste i fem Aar, og i Løbet af denne Femaarsperiode vil ingen af disse Prøver, Forsteninger eller Kærnedele eller Detailler eller Oplysninger angaaende dem blive givet eller tilstillet andre uden Selskabets forudgaaende skriftlige Samtykke; men alle saadanne Prøver, Forsteninger og Kærnedele skal være til Danmarks Geologiske Undersøgelses frie Disposition efter at Selskabets Virksomhed er ophørt i Danmark.

Parterne har fundet det rimeligt med Henblik paa nødvendige Forsyninger for Hjemmeforbruget inden for Koncessionsomraadet af ethvert af de Raastoffer, der maatte blive indvundet i Henhold til Koncessionen, og af Produkter, fabrikeret, raffineret eller paa anden Maade udvundet deraf, at fastsætte, at i Tilfælde af, at Statsministeriet paa noget Tidspunkt skulde mene, at Behovet til Hjemmeforbrug af saadanne Raastoffer, som maatte findes eller indvindes i Henhold til Koncessionen, eller Produkter deraf, som foran anført, ikke er tilstrækkelig dækket, vil Selskabet forhandle med Statsministeriet om Sagen med det Formaal bedre at afbøde Vanskelighederne. Hvis Behovet til Hjemmeforbrug efter Ministeriets Opfattelse efter disse Drøftelser stadig ikke skulde blive tilstrækkelig dækket, skal Statsministeriet have Ret til, uden at nogen særlig eller almindelig Lovgivningsakt derfor skal være nødvendig, til en fair Pris at overtage saa store Kvanta af eksiste- 
rende Beholdninger af de paagældende Raamaterialer (eller saafremt Selskabet fabrikerer, raffinerer eller paa anden Maade fremstiller Brugsvarer heraf efter Selskabets Valg af saadanne Brugsvarer), som Ministeriet finder nødvendige til Dækning af Behovet til Hjemmeforbruget inden for Koncessionsomraadet. Hvis Statsministeriet og Selskabet ikke kan enes om en fair Pris, kan hver af Parterne forelægge Spørgsmaalet paa behørig Maade til Afgørelse ved de danske Domstole.

Udfærdiget in duplo saavel paa Dansk som Engelsk i Kobenhavn, den 17. Februar 1940.

Th. Stauning,

Statsminister.

DANISH AMERICAN PROSPECTING CO

Guy Stevens,

Vicepræsident

Af skrivelse 1948 fra Ministeriet for off. arb.

Bilag L.

til Danish American Prosp. Co.

Som det vil fremgå af berelningen, hvortil ministeriet for sit vedkommende kan henholde sig, er udvalget kommet til det resultat, at saltfundet er et falsum.

$\mathrm{Da}$ det $\mathrm{i}$ indledningen til eneretsbevillingen, hvis bestemmelser er blevet bekræf. tet ved den under 17. februar 1940 afsluttede tillægsoverenskomst, udtrykkeligt er fremhævet som afgørende forudsætning for bevillingens udstedelse, at ingeniør Ravlin har fundet salt ved Harte, må ministeriet holde for, at grundlaget for bevillingen er bortfaldet.

Ministeriet må derfor forbeholde sig at hæude dette principielle standpunkt, men er villig til gennem forhandling med selskabets nuværende indehavere at søge opnået en såvel for staten som selskabet tilfredsstillende ordning, idet man gerne ser en fortsættelse af samarbejdet med selskabets nuværende indehavere, der har varet i god tro med hensyn til saltfundet på det tidspunkt, de erhvervede a'stierne fra Ravlin.

Analyser af Suldrup nr. 4.

Bilag M.

(Efter Saltudvalgets Betænkning, s. 148.)

Zone nr.

II

Dybde i meter

814,8-828,8 934,1-942,6 947,0-961,2

\begin{tabular}{|c|c|c|c|c|c|}
\hline \multirow[t]{7}{*}{ Gennemsnitlig } & $\mathrm{g} \mathrm{SO}_{4}-\cdots$ & $0 \%$ & 25,7 & 24,0 & 26,9 \\
\hline & $\mathrm{Cl}-$ & " & 31,1 & 33,4 & 29,0 \\
\hline & $\mathrm{Ca}++$ & " & 0,26 & 0,11 & 0,30 \\
\hline & $\mathrm{Mg}++$ & $"$ & 5,72 & 5,95 & 6,52 \\
\hline & $\mathrm{K}_{2} \mathrm{O}$ & a & 9,76 & 10,67 & 9,00 \\
\hline & $\mathrm{Na}+$ & » & 15,8 & 16,5 & 13,5 \\
\hline & uopl. rest & 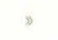 & 3,05 & 3,1 & 3,9 \\
\hline \multirow{2}{*}{\multicolumn{3}{|c|}{$\begin{array}{l}\text { Zonetykkelse i meter } \\
\text { Lagtykkelse i meter }\end{array}$}} & 14,0 & 9,5 & 14,2 \\
\hline & & & 9,9 & 3,6 & 6,0 \\
\hline
\end{tabular}

Zonetykkelse $=$ meter råkali i boringen.

Lagtykkelse $=$ virkelig tykkelse beregnet af zonetykkelse og hældning. 